\title{
“Papel dos receptores ativados por protease (PARs) na reatividade vascular de ratos espontaneamente hipertensos (SHR)"
}

Tese apresentada ao Programa de Pós-Graduação em Farmacologia do Instituto de Ciências Biomédicas da Universidade de São Paulo, para obtenção do título de Doutor em Ciências.

Área de Concentração: Farmacologia

Orientadora: Prof ${ }^{\text {a. }}$ D $^{\text {ra. }}$ Maria Helena Catelli de Carvalho 
COLAÇO, A. L. Papel dos receptores ativados por protease (PARs) na reatividade vascular de ratos espontaneamente hipertensos (SHR). 2009. 139 f. Tese de Doutorado (Farmacologia) - Instituto de Ciências Biomédicas, Universidade de São Paulo, São Paulo, 2009.

Receptores ativados por protease (PARs) pertencem à família de GPCRs. Desses, PAR-1, PAR-3 e PAR-4 são ativados por trombina, e PAR-2 por tripsina. Como as proteases, peptídeos sintéticos (PARs-AP) também ativam esses receptores. Estudamos o papel dos PARs na reatividade vascular de Wistar e SHR. In vitro, PAR-1 AP, promoveu maior vasoconstrição em aorta com endotélio (E+) de SHR vs Wistar. PAR-2 AP promoveu vasodilatação similar em aorta E+ de SHR e Wistar, enquanto PAR-4 AP e peptídeos reversos não causaram efeito. In vivo/in situ PAR-1 e PAR-2 AP mostraram intensa vasomotilidade em arteríolas mesentéricas. A expressão gênica de PAR-1 está aumentada em aorta e arteríolas de SHR, mas a expressão protéica está aumentada apenas em arteríolas. Demonstramos ainda que a vasoconstrição induzida por PAR-1 AP, é dependente de $\mathrm{Ca}^{++}$e da liberação de Ang II, ET-1 e $\mathrm{O}_{2}{ }^{-}$pelo endotélio. Assim, sugerimos que PAR-1 pode ser um alvo terapêutico para novos antihipertensivos com efeito antitrombótico, já que este receptor também tem sido envolvido em eventos tromboembólicos.

Palavras-chave: Receptor Ativado por Protease (PAR); TFLLR-NH $\mathrm{N}_{2}$; SFFLR-NH $\mathrm{N}_{2}$; SLIGRL-NH ${ }_{2} ;$ AYPGKF-NH ${ }_{2} ;$ RLFFS-NH ${ }_{2} ;$ RLLFT-NH ${ }_{2} ;$ LRGILS-NH $\mathrm{NH}_{2} ;$ FKGPYA-NH $_{2}$; Trombina; Tripsina; Reatividade Vascular; Endotélio, Microscopia intravital; Hipertensão Arterial; Ratos Espontaneamentes Hipertensos (SHR). 


\begin{abstract}
COLAÇO, A. L. Role of protease activated receptors (PARs) in vascular reactivity of spontaneously hypertensive rats (SHR). 2009. 139 p. [Doctoral thesis (Pharmacology)] Instituto de Ciências Biomédicas, Universidade de São Paulo, São Paulo, 2009.

Protease activated receptors are a new GPCRs family. The PAR-1, PAR-3 and PAR-4 are activated by thrombin and PAR-2 by tripsin. Like proteases, synthetic peptides (PARs-AP) can also activate those receptors. We studied the role of PARs in vascular reactivity of Wistar and SHR. In vitro, PAR-1 promoted higher vasoconstriction to PAR-1 AP in SHR aorta with endothelium $(\mathrm{E}+)$ than the Wistar ones. PAR-2 AP produced similar vasodilation in Wistar and SHR aorta E+, while neither PAR-4 nor reverse peptides presented any effect. In vivo/in situ PAR-1 and PAR-2 showed an intensive vasomotion in mesenteric vessels. PAR-1 gene expression was increased in SHR aorta and arterioles, while the protein expression was increased only in the arterioles. We have also shown that the vasoconstriction induced by PAR-1 AP, is $\mathrm{Ca}^{++}$-dependent and Ang II, ET-1 and $\mathrm{O}_{2}^{-}$release from endothelium. Thus, we suggest that PAR-1 might represent a therapeutic target to new antihypertensive drugs with antithrombotic effect, since this receptor has been involved in thromboembolics events.
\end{abstract}

Keywords: Protease activated receptor (PAR); TFLLR-NH $\mathrm{NH}_{2}$ SFFLR-NH $\mathrm{SH}_{2}$ SLIGRL-NH $\mathrm{S}_{2}$;

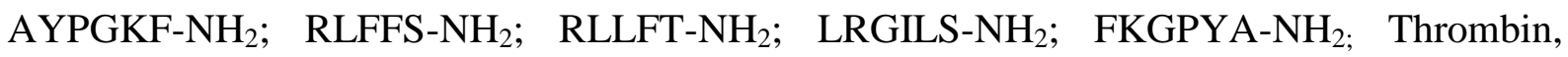
Trypsin, Vascular reactivity, Endothelium, Intravital microscopy, Arterial hypertension, Spontaneously hypertensive rats (SHR). 


\section{INTRODUÇÃO}

\subsection{Hipertensão arterial}

A hipertensão arterial é uma entidade clínica multifatorial, definida por "níveis de pressão sistólica $\geq 140 \mathrm{mmHg}$ e/ou níveis de pressão diastólica $\geq 90 \mathrm{mmHg}$ em indivíduos que não estão em uso de medicação", 1 que é forte preditora de diversos eventos cardiovasculares incluindo, dentre outros, hipertrofia ventricular esquerda ${ }^{\mathbf{2 , 3}}$, distúrbios na circulação coronariana, ${ }^{4}$ mudanças nas estruturas do miocárdio ${ }^{5}$ e morte ${ }^{\mathbf{3 , 6}}$. Ela explica $40 \%$ das mortes por acidente vascular encefálico (AVE) e $25 \%$ daquelas por doença arterial coronariana ${ }^{7}$. A hipertensão arterial é, portanto, um dos mais importantes fatores de risco para o desenvolvimento de doenças cardiovasculares.

Estudos de base populacional realizados em algumas cidades do Brasil apontam alta prevalência de hipertensão arterial. Segundo o critério atual de diagnóstico (140/90 mmHg), as taxas de prevalência na população urbana adulta brasileira em estudos selecionados variam de $22,3 \%$ a $43,9 \%{ }^{\mathbf{8 - 1 3}}$. A hipertensão arterial e suas complicações também são responsáveis por alta freqüência de internações. A insuficiência cardíaca é a principal causa de hospitalização entre as afecções cardiovasculares, sendo duas vezes mais freqüente do que as internações por AVE. De acordo com dados do Ministério da Saúde, em 2005 ocorreram 1.180.184 internações por doenças cardiovasculares, com custo global de 1.323.775.008,28 de reais $^{14}$.

A redução da pressão arterial (PA) possui efeitos notáveis sobre a incidência e a taxa de mortalidade da cardiopatia isquêmica, insuficiência cardíaca e $\mathrm{AVE}^{\mathbf{1 5}}$. Desse modo, o uso de fármacos antihipertensivos tem resultado em diminuição da morbidade e mortalidade por $\mathrm{AVE}^{16}$ e insuficiência renal ${ }^{17}$, porém, redução similar nas mortes relacionadas à doença cardíaca isquêmica não tem sido conseguida ${ }^{\mathbf{1 8}}$. Isto poderia ser, em parte, devido aos efeitos desfavoráveis de um "estado hipercoagulável" na hipertensão. Assim, agentes antihipertensivos que proporcionem benefícios na redução deste "estado hipercoagulável" poderiam ter vantagens adicionais em reduzir a ocorrência de AVE e outros eventos trombóticos ${ }^{19}$.

Das diversas causas de hipertensão arterial, cerca de 85 a $90 \%$ são idiopáticas e aparentemente primárias. Estes casos apresentam etiologia desconhecida, e parece improvável que uma única causa explique suas diversas alterações hemodinâmicas e fisiopatológicas. A hipertensão primária é considerada uma doença poligênica e estima-se que em torno de 100 
dos 70000 genes que compõe o genoma humano estejam envolvidos com a hipertensão arterial. Fatores ambientais, usualmente nutricionais (como dietas hiperssódicas, hipocálcicas, hipocalêmicas, hipercalóricas - levando a obesidade, bem como o excesso de álcool, dentre outras), mas também fatores psicossociais, como o estresse, parecem agir em indivíduos geneticamente suscetíveis. A hipertensão arterial seria, portanto, o resultado da interação de fatores genéticos e ambientais ${ }^{\mathbf{2 0}}$. Esses dados demonstram a importância do estudo da fisiopatologia da hipertensão arterial, principalmente nos casos de hipertensão arterial primária.

Nos casos de hipertensão arterial secundária, diferentemente da primária, a etiologia é conhecida e pode estar associada à doença parenquimatosa renal bilateral ou a distúrbios potencialmente curáveis como feocromocitoma, síndrome de Cushing, aldosteronismo primário, uso de contraceptivos, ingestão excessiva de álcool, dentre outros ${ }^{1}$. Estes casos representam cerca 5 a $10 \%$ dos casos de hipertensão arterial, dos quais apenas 1 ou $2 \%$ são potencialmente curáveis ${ }^{\mathbf{2 0}}$.

A magnitude da pressão arterial depende de duas variáveis hemodinâmicas fundamentais: o débito cardíaco (DC) e a resistência vascular periférica total (RVPT) ${ }^{\mathbf{1 5}}$, visto que ela é produto desses fatores, ou seja, PA = DC x RVPT. Assim, os mecanismos patogenéticos da hipertensão arterial devem levar ao aumento do DC, da RVPT, ou a ambos ${ }^{\mathbf{2 0}}$.

O débito cardíaco é influenciado pela frequência cardíaca (FC) e pelo volume sanguíneo (VS) que depende em grande parte, da quantidade de sódio corporal. Por conseguinte, a homeostasia do sódio é fundamental para a regulação da pressão arterial. O aumento primário no débito cardíaco resulta de uma anomalia básica não-estrutural, provavelmente genética, levando a uma menor eliminação renal de sódio na presença de uma pressão arterial normal (defeito na natriurese por pressão). Assim, a menor excreção de sódio aumentaria a volemia e o débito cardíaco. ${ }^{15}$.

A resistência vascular periférica total, na maior parte das vezes, é determinada no nível das arteríolas e depende, principalmente, do tamanho da luz dos vasos que, por sua vez, depende da espessura da parede arteriolar e dos efeitos de influências neurais e hormonais que contraem ou dilatam estes vasos. Dessa forma, o tônus vascular normal depende do equilíbrio entre influências vasoconstritoras, como a angiotensina II (Ang II), catecolaminas, tromboxano, leucotrienos e endotelina, dentre outras; e vasodilatadoras, como cininas, prostaglandinas, óxido nítrico, e outras. Alguns produtos metabólicos (tais como o ácido láctico, íons hidrogênio e adenosina) e a hipóxia, também podem atuar como vasodilatadores locais. Uma propriedade intrínseca dos vasos de resistência é a auto-regulação, um processo 
pelo qual um aumento do fluxo sanguíneo nestes vasos induz vasoconstrição. Este é um mecanismo essencialmente adaptativo, que protege contra a hiperperfusão tecidual, sendo provavelmente mediada pelos níveis locais de adenosina. Dessa forma, o endotélio vascular tem papel primordial, pois controla as respostas vasculares locais, através da liberação ou ação de substâncias vasodilatadoras e/ou vasoconstritoras, em resposta a alterações do fluxo sanguíneo e agentes vasoativos, modulando assim o tônus vascular e controlando a RVPT ${ }^{\mathbf{1 5}}$.

\subsection{Endotélio vascular}

O endotélio vascular é uma monocamada de epitélio pavimentoso que reveste internamente os vasos sanguíneos e faz interface entre sangue e músculo liso vascular, cobrindo uma área de aproximadamente $700 \mathrm{~m}^{2}$ e com cerca de 1 a $1,5 \mathrm{~kg}$ em indivíduos com peso corpóreo de $70 \mathrm{~kg}$. Até o final da década de 1970, o endotélio era considerado apenas uma barreira semipermeável inerte que mantinha a estrutura da parede vascular e regulava a transferência de pequenas e grandes moléculas entre o sangue e células musculares. A descoberta da importante participação do endotélio na modulação do tônus vascular foi feita por Furchgott e Zawadski ${ }^{21}$ ao observarem que o relaxamento induzido pela acetilcolina, em anéis de aorta de coelho, era totalmente dependente da presença e integridade da célula endotelial. Nesse estudo foi demonstrado que a acetilcolina, ao interagir com a célula endotelial, liberava uma substância que se difundia para o músculo liso vascular promovendo relaxamento, a qual foi denominada Fator Relaxante Derivado do Endotélio ("EndotheliumDerived Relaxing Factor" - EDRF) ${ }^{\mathbf{2 1}}$. O endotélio passou, então, a ser considerado um órgão endócrino ativo que, em resposta a estímulos humorais, neurais e mecânicos, sintetiza e libera substâncias vasoativas que modulam tônus, calibre vascular e fluxo sanguíneo, desempenhando papel fundamental na regulação da circulação ${ }^{22}$. Assim, diversas substâncias endógenas que participam da manutenção do tônus vascular, como noradrenalina, 5-hidroxitriptamina, angiotensina II, bradicinina, histamina, trombina dentre outras, podem ser sintetizadas pelo endotélio vascular ou agir neste ${ }^{\mathbf{2 3}}$.

Dentre as substâncias vasoativas liberadas pelo endotélio destacam-se diversos fatores relaxantes derivados do endotélio (EDRFs), como o óxido nítrico (NO), a prostaciclina $\left(\mathrm{PGI}_{2}\right)$ e os fatores hiperpolarizantes derivados do endotélio ("Endothelium-Derived Hyperpolarizing Factors - EDHFs"), que podem ser metabólitos do ácido araquidônico (AA), derivados da enzima do citocromo P450, endocanabinóides, ou outras substâncias (Figura 1) ${ }^{\mathbf{2 0 , 2 3}}$. 


\section{Fatores Relaxantes Derivados do Endotélio (EDRF's)}

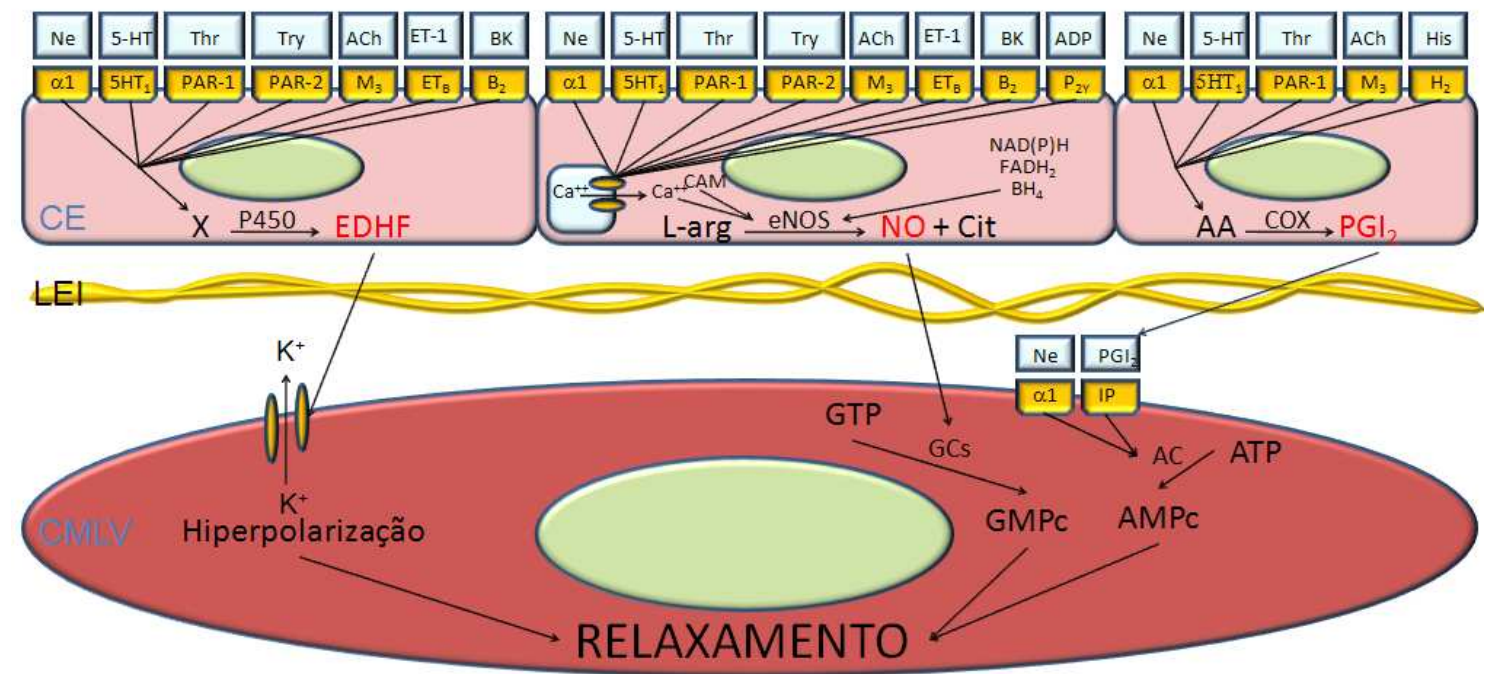

Figura 1 - Esquema representativo dos fatores relaxantes derivados do endotélio e dos principais agonistas que liberam esses fatores. $\mathrm{Ne}=$ norepinefrina; 5-HT $=$ 5-hidroxitriptamina (serotonina); Thr = trombina; Try = Tripsina; $\mathrm{ACh}=$ acetilcolina; $\mathrm{ET}-1=$ endotelina $-1 ; \mathrm{BK}=$ bradicinina; $\mathrm{ADP}=$ difosfato de adenosina; $\mathrm{PGI}_{2}=$ prostaciclina; $\mathrm{CE}=$ célula endotelial; $\mathrm{CMLV}=$ célula do músculo liso vascular; LEI = lâmina elástica interna; eNOS = óxido nítrico sintase endotelial; $\mathrm{Cit}=$ citrulina; $\mathrm{L}$-arg = L-arginina; $\mathrm{CaM}=$ calmodulina; $\mathrm{BH}_{4}=$ tetrahidropterina; $\mathrm{NO}=$ óxido nítrico; $\mathrm{NAD}(\mathrm{P}) \mathrm{H}$ = fosfato de nicotiamina adenina dinucleotídeo; $\mathrm{FADH}_{2}=$ flavina adenina dinucleotídeo; $\mathrm{EDHF}$ = fator hiperpolarizante derivado do endotélio; $\mathrm{AA}$ = ácido araquidônico; COX = cicloxigenase; GTP = trifosfato de guanosina; GMPc = monofosfato cíclico de guanosina; GCs = guanilato ciclase solúvel; ATP = trifosfato de adenosina; AMPc $=$ monofosfato cíclico de adenosina; $\mathrm{AC}=$ adenilato ciclase $; \mathrm{Ca}^{++}=$cálcio; $\mathrm{K}^{+}=$potássio. Para detalhes veja texto.

As células endoteliais também produzem diversos fatores constritores ("Endothelium Derived Constrictor Factors - EDCFs"; Figura 2). Dentre eles temos o $\mathrm{EDCF}_{1}$, que são prostanóides, como o tromboxano $\mathrm{A}_{2}\left(\mathrm{TXA}_{2}\right)$ e a prostaglandina $\mathrm{H}_{2}\left(\mathrm{PGH}_{2}\right)$; o $\mathrm{EDCF}_{2}$, representado pelas endotelinas (ET-1, ET-2 e ET-3); o $\mathrm{EDCF}_{3}$, liberado em condições de hipóxia grave; e outras substâncias vasoconstritoras, como a Ang II e espécies reativas do oxigênio (EROs), como o ânion superóxido $\left(\mathrm{O}_{2}^{-}\right)^{\mathbf{2 0 , 2 3}}$. 


\section{Fatores Constritores Derivados do Endotélio (EDCF's)}

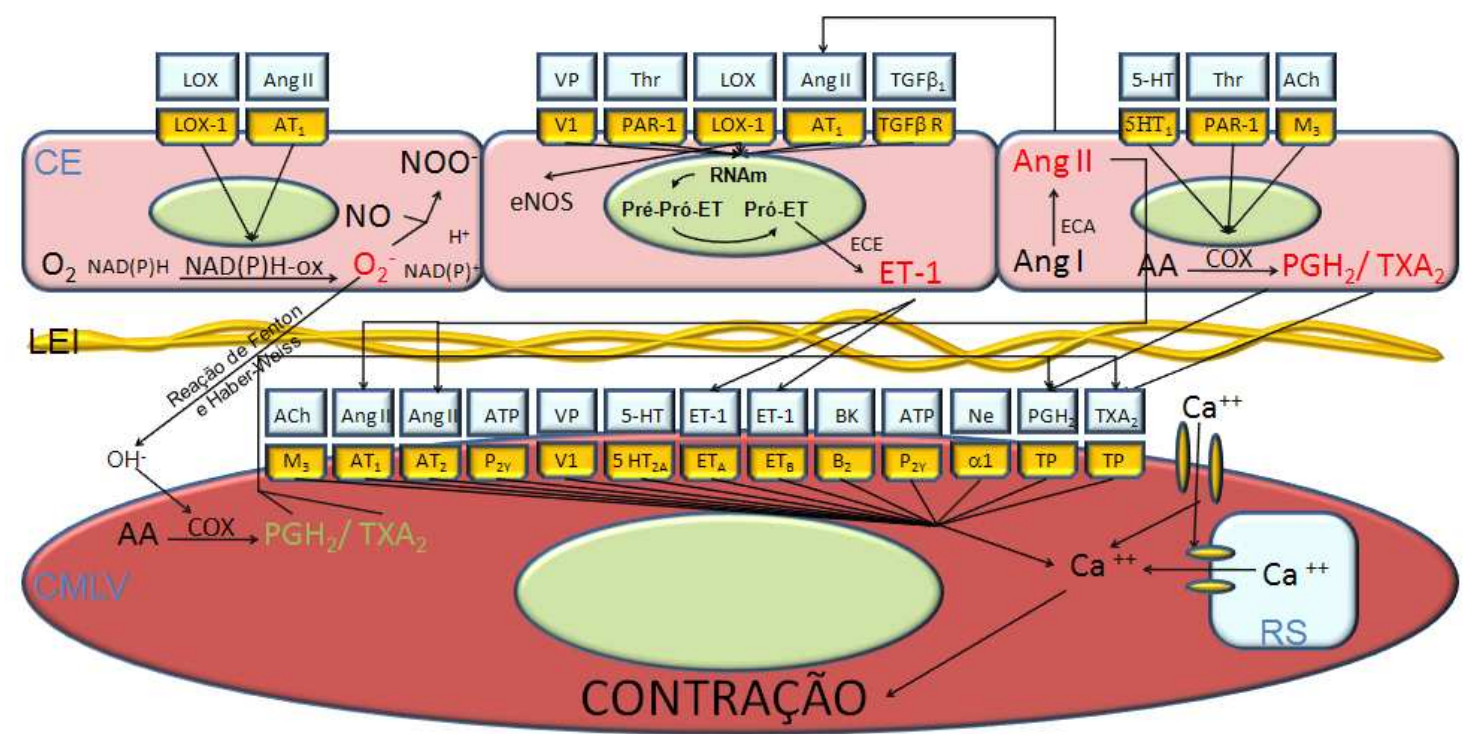

Figura 2 - Esquema representativo dos fatores constritores derivados do endotélio e dos principais agonistas que liberam esses fatores. LOX = LDL oxidada; Ang II = angiotensina II; Ang I = angiotensina I; ECA = enzima conversora de angiotensina; VP = vasopressina; Thr = trombina; TGF- $\beta$ = fator de necrose tumoral $\beta$; Ne = norepinefrina; 5-HT = 5-hidroxitriptamina (serotonina); $\mathrm{ACh}=$ acetilcolina; ET-1 = endotelina- $1 \mathrm{BK}=$ bradicinina; $\mathrm{ATP}=$ trifosfato de adenosina; $\mathrm{PGH}_{2}=$ prostaglandina $\mathrm{H}_{2}$; $\mathrm{TXA}_{2}=$ tromboxano $\mathrm{A}_{2} ; \mathrm{CE}$ = célula endotelial; CMLV = célula do músculo liso vascular; $\mathrm{LEI}$ = lâmina elástica interna; $\mathrm{RS}$ = retículo sarcoplasmático; eNOS = óxido nítrico sintase endotelial; $\mathrm{NO}=$ óxido nítrico; $\mathrm{NAD}(\mathrm{P}) \mathrm{H}-\mathrm{ox}=$ fosfato de nicotiamina adenina dinucleotídeo oxidase; $\mathrm{O}_{2}=$ oxigênio; $\mathrm{O}_{2}{ }^{-}=$ânion superóxido; $\mathrm{OH}^{-}=$hidroxila; $\mathrm{ECE}=$ enzima conversora de endotelina RNAm = ácido ribonucléico mensageiro; Pré-Pró-ET = pré-próendotelina; $\mathrm{AA}=$ ácido araquidônico; $\mathrm{COX}=$ cicloxigenase; $\mathrm{Ca}^{++}=$cálcio. Para detalhes veja texto.

Além da modulação do tônus vascular, o endotélio controla a permeabilidade vascular, mantém uma interface sangue-tecido não-trombogênica (regulando a trombose e trombólise), bem como controla a adesão de plaquetas e leucócitos, além contribuir de forma importante para angiogênese, modulando o crescimento do músculo liso ${ }^{23}$. O endotélio participa também da fibrinólise, metabolismo de lipoproteínas, apresentação de antígenos de histocompatibilidade ${ }^{24}$, dentre outras importantes funções. Dessa forma, em resposta a estímulos humorais, neurais e mecânicos, as células endoteliais controlam, através de receptores específicos ou modificações diretas nas vias de sinalização, as principais funções vasculares. Portanto, qualquer alteração na função endotelial pode ser compreendida em termos de disfunção endotelial ${ }^{\mathbf{2 4}}$. 


\subsection{Disfunção endotelial, hipertensão arterial e estado de hipercoagulação}

O termo "disfunção endotelial" refere-se a um desequilíbrio na produção endotelial de mediadores que regulam o tônus vascular, agregação plaquetária, coagulação e fibrinólise, sendo o tônus vascular o aspecto mais estudado. A disfunção endotelial também é freqüentemente referida como piora no relaxamento dependente do endotélio, causado por diminuição na biodisponibilidade do NO. Entretanto, visto que a produção de outras substâncias derivadas do endotélio (como a $\mathrm{PGI}_{2}$, EDHF, ET-1, Ang II, TXA 2 , etc.) também pode estar alterada, esta definição não reflete por completo a amplitude do termo "disfunção

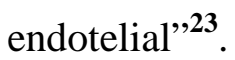

A disfunção endotelial é uma das características importantes da hipertensão arterial e tem sido descrita na macrocirculação, bem como na microcirculação e na circulação renal. Nesse contexto, a parede dos vasos de hipertensos exibe reduzido relaxamento dependente do endotélio e que dependendo da causa da hipertensão, pode ser devido a uma menor liberação ou efeito reduzido do fator de relaxamento derivado do endotélio (EDRF) ou do fator hiperpolarizante derivado do endotélio $(\mathrm{EDHF})^{\mathbf{2 5}}$. Entretanto, na hipertensão arterial primária, a disfunção endotelial parece ser devida a uma maior propensão à liberação de fatores constritores derivados do endotélio $\left(\mathrm{EDCF}^{\mathbf{2}}\right)^{\mathbf{2 6}}$. Porém, ainda não está claro se a disfunção endotelial é causa ou conseqüência da hipertensão arterial ${ }^{\mathbf{2 3}}$.

Diversos modelos experimentais de hipertensão arterial têm demonstrado a presença de disfunção endotelial. Em aorta de ratos Dahl sensíveis ao sal, o relaxamento dependente do endotélio para a acetilcolina está diminuído, sugerindo uma liberação reduzida do $\mathrm{NO}^{\mathbf{2 6}}$. $\mathrm{O}$ relaxamento dependente do endotélio também está reduzido em artérias e arteríolas de ratos espontaneamente hipertensos (SHR), bem como em outros modelos animais e, inclusive em humanos ${ }^{27}$.

Em pacientes hipertensos, a piora da resposta à acetilcolina, bradicinina e substância $\mathrm{P}$ tem sido encontrada na vasculatura do antebraço, enquanto a resposta vascular independente do endotélio ao nitroprussiato de sódio permanece normal ${ }^{28,29}$. Dessa forma, a disfunção endotelial que se apresenta na hipertensão arterial humana envolve menor biodisponibilidade do NO, resultado tanto do aumento do estresse oxidativo, quanto da liberação aumentada de EDCF's como endoperóxidos e tromboxanos, EROs e/ou ET-1 pelo endotélio vascular ${ }^{30}$. Os mecanismos responsáveis pela geração aumentada desses radicais livres, como o $\mathrm{O}_{2}^{-}$, não estão claros, embora a ativação do receptor $\mathrm{AT}_{1}$ pela Ang II e conseqüente estimulação do sistema NAD(P)H oxidase possa estar envolvida ${ }^{\mathbf{3 0}}$. 
Outro aspecto importante da disfunção endotelial, é que a piora da vasodilatação dependente do endotélio está freqüentemente acompanhada pela desregulação da interação célula sangüínea-endotélio, o que pode levar a inflamação localizada, lesão vascular severa e trombose $^{\mathbf{3 1}}$. Nesse contexto, diversas evidências têm demonstrado uma associação entre doença vascular hipertensiva e trombose. A atenção mais recente tem sido direcionada para a inflamação e disfunção endotelial, especialmente porque a inflamação pode promover disfunção endotelial e está intimamente relacionada à trombogênese e aterosclerose $\mathrm{e}^{\mathbf{3 2}}$.

Dessa forma, a hipertensão arterial tem sido associada a um "estado protrombótico" ou "hipercoagulável"19, pois, muito embora os vasos sanguíneos sejam expostos a altas pressões, suas principais complicações, tais como AVE e infarto do miocárdio, são paradoxalmente mais trombóticas do que hemorrágicas, o assim chamado "paradoxo trombótico da hipertensão" (ou "paradoxo de Birmingham") ${ }^{\mathbf{3 3}}$. Isso se deve ao fato de que sob certas condições patogênicas onde a disfunção endotelial está presente, como no caso da hipertensão arterial, as propriedades antitrombóticas da parede vascular encontram-se alteradas, ou seja, a parede vascular torna-se protrombótica e pró-coagulante, diferente do que ocorre sob condições fisiológicas normais, onde o endotélio saudável mantém uma superfície anticoagulante e antitrombótica devido à presença de diversas substâncias como a trombomodulina, sulfato de heparan, prostaciclina e óxido nítrico ${ }^{22}$.

A hipótese de que a hipertensão arterial possa conferir um estado protrombótico ou hipercoagulável pode ser examinada através da cuidadosa referência a tríade de Virchow ${ }^{\mathbf{3 4 - 3 6}}$, o qual a mais de 150 anos reconheceu três pré-requisitos para o processo de trombogênese: anormalidades na parede dos vasos, anormalidades dos constituintes do sangue e fluxo sanguíneo anormal ${ }^{\mathbf{3 4}}$. Nesse contexto, a hipertensão arterial pode causar lesão ao endotélio (“anormalidade nos vasos sanguíneos”), como é evidente nas anormalidades da vasodilatação mediada por fluxo e anormalidades de marcadores específicos das células endoteliais, sugerindo lesão ou disfunção endotelial ${ }^{37,38}$. Anormalidades dos constituintes do sangue, como coágulos ou fatores hemostáticos e ativação plaquetária, também ocorrem na hipertensão $\operatorname{arterial}^{\mathbf{3 6}}$. O componente final da tríade de Virchow, que são anormalidades no fluxo sanguíneo, também ocorrem em hipertensos, com anormalidades nos fatores hemorreológicos ${ }^{39}$, na complacência arterial $^{40}$ e reduzido fluxo de reserva coronariano ${ }^{41}$. Assim, anormalidades nos fatores hemorreológicos podem estar envolvidas nas complicações da hipertensão arterial, bem como na determinação da pressão arterial por si própria ${ }^{39}$. A quantidade de evidências de que esses marcadores são de valor prognóstico também levanta a possibilidade de que eles não são meramente marcadores ou consequências da doença 
aterotrombótica, mas que podem contribuir especialmente para a patogênese da hipertensão e suas complicações ${ }^{\mathbf{3 6}, 42}$.

Assim, corroborando com a hipótese de que a hipertensão arterial pode conferir um estado protrombótico ou hipercoagulável, Sawada K. et $a l .{ }^{43}$ tem sugerido que a hipertensão pode diminuir os níveis plasmáticos de trombomodulina e induzir um estado hipercoagulável em ratos. Eles demonstraram que os níveis plasmáticos de trombomodulina diminuem com a idade, entre 5 e 20 semanas de idade, tanto em SHR quanto em WKY, e foram menores em SHR do que em WKY com idade pareada em todas as idades examinadas. Os ratos hipertensos DOCA-sal também apresentaram níveis diminuídos de trombomodulina comparados com ratos normotensos WKY. Também foi observada coagulação e fibrinólise acelerada demonstrada pelo aumento no complexo trombina-antitrombina (TAT) e os níveis de D-dímero foram observados nos grupos de ratos hipertensos ${ }^{\mathbf{4 3}}$. Huzoor-Akbar et al. ${ }^{\mathbf{4 4}}$ também tem demonstrado que a trombina induz agregação plaquetária significantemente maior em SHR do que em WKY e sugerem que a sensibilidade plaquetária à trombina está aumentada na hipertensão e pode ser devida à transdução do sinal alterada e não devido a mudanças no número ou afinidade dos receptores da trombina ${ }^{44}$.

Tem sido ainda demonstrado que as plaquetas de animais e humanos hipertensos apresentam maior tendência a degranular e mostram aumentada adesividade in vitro ${ }^{\mathbf{4 5}}$. Estudos clínicos também tem mostrado níveis circulantes aumentados de proteínas prótrombóticas como o inibidor do ativador do plasminogênio (PAI-1), fator de von Willenbrand (vWF) e fibrinogênio em pacientes hipertensos ${ }^{46}$.

Nesse contexto, a exposição das células endoteliais à trombina, uma serina protease ativada no passo final da cascata de coagulação sanguínea, resulta em uma grande variedade de respostas funcionais que em sua maioria são devidas à interação especifica da trombina com receptores de alta afinidade na superfície celular, denominados receptores ativados por proteases (PARs). Estes receptores têm sido relacionados à fenômenos tromboembólicos, aumento da permeabilidade vascular, proliferação do músculo liso, bem como regulação do tônus vascular, sugerindo assim uma importante participação na fisiopatologia da hipertensão arterial. 


\subsection{Receptores ativados por proteases (PARs)}

\subsubsection{Descoberta e estrutura}

Em 1991, o primeiro receptor ativado por protease (ou proteinase), PAR-1, foi identificado como sendo o receptor para trombina ${ }^{47}$. Subsequentemente, um segundo PAR (PAR-2) foi identificado como sendo insensível à trombina, mas prontamente ativado pela tripsina $^{\mathbf{4 8}}$ e outras serina-proteases (ex.: triptase de mastócitos e fator de coagulação Xa) ${ }^{\mathbf{4 9 , 5 0}}$. Sucessivamente, PARs adicionais foram clonados, sendo o PAR-3 ativado pela trombina ${ }^{\mathbf{5 1}} \mathrm{e}$ PAR-4, ativados por ambos, tripsina e trombina ${ }^{\mathbf{5 2 , 5 3}}$.

Todos os PARs pertencem à família dos receptores acoplados à proteína G (GPRC), e apresentam sete domínios transmembrana ${ }^{\mathbf{5 4 , 5 5}}$. Seu mecanismo de ativação é único (Figura 3), no qual as proteases agonistas clivam o domínio extracelular $\mathrm{N}$-terminal em um local específico, e o novo N-terminal produzido age como próprio ligante para os PARs, iniciando eventos de sinalização intracelular que promovem diversas respostas celulares ${ }^{\mathbf{5 4 , 5 5}}$. Assim, a clivagem limitada da região extracelular $\mathrm{N}$-aminoterminal no local específico expõe um novo N-terminal, que age como um "ligante amarrado", que se liga a $2^{\text {a }}$ alça extracelular do receptor, e ativa eventos de sinalização intracelular. Dessa forma, as proteases não se ligam apenas ao receptor e o ativam como um agonista convencional, mas a atividade proteolítica é requerida para sua ativação. Isto é comprovado, pois a mutação no local de clivagem torna o receptor não responsivo às proteases ${ }^{47}$. Os locais ativados por clivagem do PAR-1, PAR-2, PAR-3 e PAR-4 são respectivamente os resíduos dos aminoácidos 41-42, 36-37, 38-39 e 4748 em humanos ${ }^{55}$.

Outro aspecto importante deste novo mecanismo de ativação destes receptores é que apenas uma molécula de protease agonista, como a trombina, pode ativar múltiplos receptores, em contraste à maioria dos eventos mediados pelos receptores convencionais, no qual a ocupação do receptor pelo ligante é necessária para manter um estado ativo. Assim, a magnitude dos eventos mediados por essas proteases é fortemente influenciada pela concentração do receptor. 


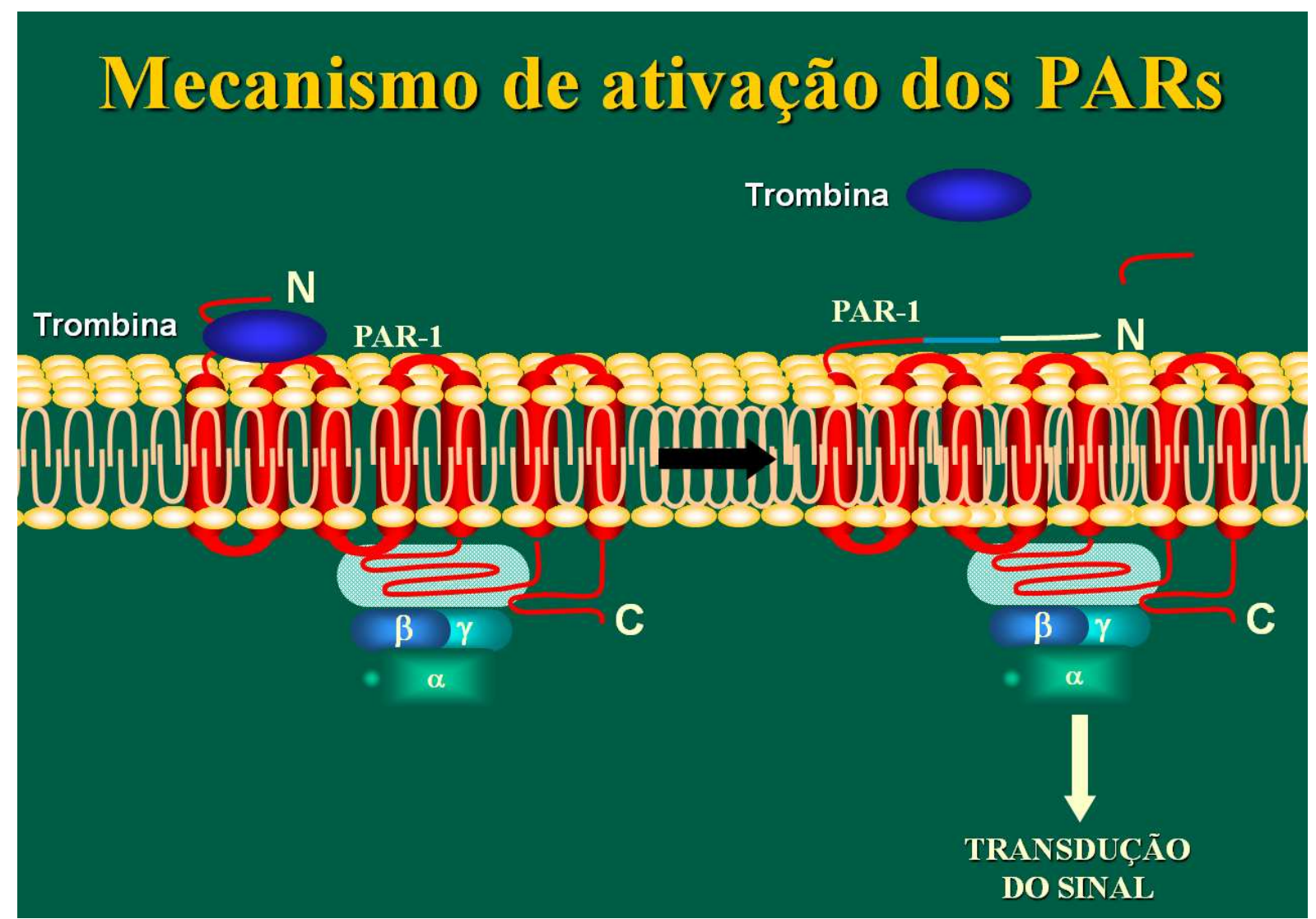

Figura 3 - Figura representativa do mecanismo de ativação dos receptores ativados por proteases (PARs). Nota-se a ativação feita por clivagem proteolítica, neste caso pela trombina, e subsequiente ativação do receptor PAR-1. Para detalhes veja texto.

\subsubsection{Proteases agonistas dos PARs}

Diversas proteases têm demonstrado ativar os PARs, como por exemplo a trombina, uma serina protease multifuncional com atividade pró-coagulante, bem como com alguns efeitos anticoagulantes homeostáticos importantes. A trombina é ativada no passo final da cascata de coagulação sanguínea e converte fibrinogênio em fibrina, apresentando dessa forma atividade pró-coagulante. Por outro lado, ela se liga a trombomodulina expressa na superfície da célula endotelial, que é o principal "tampão" fisiológico para os efeitos prócoagulantes da trombina nos vasos normais. Como a trombomodulina se liga à trombina no mesmo local que poderia ligar o fibrinogênio, plaquetas ou fator $\mathrm{V}(\mathrm{FV})$, todas essas funções são bloqueadas. Além disso, o complexo trombina-trombomodulina ativa a proteína $\mathrm{C}$ (através de um diferente local na molécula de trombina), resultando na iniciação da via da proteína $\mathrm{C}$ ativada ${ }^{\mathbf{5 6}}$. Este processo é aumentado por receptores endoteliais da proteína $\mathrm{C}$ (EPCR). A proteína $\mathrm{C}$ ativada pode então, dissociar-se do EPCR antes dele poder ligar-se a proteína $\mathrm{S}$ e agir como um efetivo anticoagulante através da inativação do fator Va (FVa). 
Além dos seus efeitos pró-coagulantes e anticoagulantes, a trombina está também envolvida no processo inflamatório e pode regular crescentemente ("up-regulation") a expressão de P-selectina através do fator de von Willenbrand (vWF) ${ }^{\mathbf{5 7}}$. A trombina é também um quimiotático para leucócitos polimorfonucleares e é um potente indutor da expressão do fator ativador de plaquetas (PAF) nas células endoteliais ${ }^{\mathbf{5 8}}$. Dessa forma, a exposição das células endoteliais à trombina resulta em uma grande variedade de respostas funcionais.

A trombina também é conhecida por exercer muitos efeitos celulares, incluindo estimulação do crescimento celular, aumento na concentração citossólica de $\mathrm{Ca}^{++}$, produção de 3,4,5 trifosfato de inositol $\left(\mathrm{IP}_{3}\right)$, supressão do nível de AMP cíclico e a associação da fosfatidil inositol 3-quinase com o "não-receptor tirosina quinase",59-64. A trombina assim, não age somente como um fator de coagulação e promove formação de trombo, mas também age na estimulação celular e promove ativação plaquetária, controle da reatividade vascular, proliferação do músculo liso, aumento da permeabilidade vascular e, portanto, pode contribuir para o desenvolvimento das doenças vasculares.

A maioria ou todos esses efeitos são devidos à interação especifica da trombina com os receptores PARs. Assim, a trombina tem sido sugerida como uma protease agonista para PAR-1, PAR-3 e PAR-4 ${ }^{\mathbf{5 4 , 5 5}}$. PAR-1 e PAR-3 são ativados pela trombina por um mecanismo de 2 passos: primeiro, a protease liga-se e, posteriormente, cliva o receptor.

O processo de ligação e ativação desses receptores tem sido mais bem estudado para trombina e PAR-1 ${ }^{65}$. Assim, o terminal amino-extracelular do PAR-1 humano contém uma seqüência de resíduos carregados $\left(\mathrm{D}^{51} \mathrm{KYEPF}^{56}\right)$, que é distal ao local de clivagem da trombina (Figura 4). Este domínio carregado liga-se a um sítio aniônico na trombina, concentrando temporariamente a protease na superfície do receptor. Esta região carregada negativamente do PAR-1 assemelha-se a um domínio do anticoagulante hirudina (presente em sanguessugas), que inibe a trombina por ligar-se ao seu sítio aniônico ${ }^{\mathbf{5 5}}$.

A importância do domínio semelhante à hirudina (Figura 4) é enfatizada pela descoberta de que sua deleção marcadamente diminui a capacidade da trombina ativar PAR-1, enquanto que a substituição desta região com o domínio correspondente da hirudina segue-se a uma recuperação total da atividade. Além disso, a $\gamma$-trombina que não tem o sítio aniônico, é 100 vezes menos potente do que a $\alpha$-trombina, que apresenta tal local, clivando o PAR-1 no local de ativação ${ }^{\mathbf{6 6}}$. Além do mais, as plaquetas respondem a baixas concentrações de $\alpha$ trombina, mas não a de $\gamma$-trombina, porque esta não se liga ao PAR-1 ${ }^{67}$. Portanto, a ligação da 
protease aumenta a eficiência da ativação, provavelmente por concentrar a protease na superfície do receptor ou por alterar a conformação do receptor para facilitar a clivagem.

O PAR-3 também contém um domínio semelhante à hirudina (FEEFP) que é distal ao local de clivagem, mas que interage com a trombina ${ }^{\mathbf{5 1}}$ (Figura 4). Assim, a $\gamma$-trombina também é 100 vezes menos potente que a $\alpha$-trombina para a ativação de PAR-3, e as substituições da alanina dentro do domínio semelhante à hirudina no PAR-3 atenua sua ativação pela trombina. O PAR-4, em contraste aos outros receptores para trombina, não tem um local de ligação para a trombina É por esta razão que ambas, $\gamma$-trombina e $\alpha$-trombina, podem ativar PAR-4 com uma potência 50 vezes menor do que a ativação do PAR-1. Assim, PAR-4 é um receptor de baixa afinidade para a trombina, enquanto PAR-1 e PAR-3 são receptores de alta afinidade para a trombina ${ }^{\mathbf{5 2 , 5 3}}$.

Outra importante protease ativadora dos PARs é a tripsina. Há ao menos 3 genes distintos para a tripsina em humanos: tripsina I, tripsina II e mesotripsina; a tripsina IV é um "splice" variante da mesotripsina. As tripsinas potencialmente ativam PAR-1, PAR-2 e PAR$4^{\mathbf{5 4 , 5 5}}$ e o seu potencial de sinalizarem para as células clivando PAR-2 e PAR-4 depende da liberação de um zimogênio - o tripsinogênio, da presença da enteropeptidase que ativa o tripsinogênio e da existência de uma grande gama de inibidores endógenos da tripsina. Dessa forma, durante a alimentação, os tripsinogênios I e II são secretados do pâncreas para o lúmen do intestino delgado, onde são ativados por uma enteropeptidase ${ }^{68}$. Os tripsinogênios pancreáticos são também prematuramente ativados no pâncreas inflamado onde são liberados no fluído intersticial e vasculatura, e podem ativar PAR-2 no ácino pancreático, células do ducto e nervos ${ }^{69}$.

As tripsinas são amplamente distribuídas e expressas em muitas células extrapancreáticas, incluindo células endoteliais ${ }^{70}$, células epiteliais, sistema nervoso ${ }^{71} \mathrm{e}$ em tumores $^{72}$. KOSHIKAWA et al. ${ }^{\mathbf{7 0}}$, demonstraram que a produção de tripsina pelas células endoteliais, poderia representar um papel fisiológico, ou fisiopatológico para a mesma, embora classicamente, a tripsina, não tenha sido considerada um agonista fisiológico no sistema cardiovascular, visto que ela é uma enzima digestiva ${ }^{\mathbf{7 0}}$. Entretanto, apesar desta ampla distribuição, quase nada é conhecido sobre o controle da secreção ou ativação das tripsinas extra-hepáticas ou suas funções potenciais como ativadores dos PARs.

Outras proteases podem ainda ativar os PARs. Assim, alguns estudos têm demonstrado que a triptase de mastócitos é ativadora do PAR-2 ${ }^{73-78}$, mas que ela é consideravelmente menos potente do que a tripsina. Importante ressaltar que a maioria das 
preparações utilizadas nesses estudos comumente contém diversas formas de triptase. Nesse contexto, os mastócitos humanos expressam ao menos 5 tipos distintos de genes para a triptase: $\alpha, \beta$ I, $\beta$ II, $\beta$ III e triptase transmembrana, sendo que também existem "splices" variantes. Assim, a forma de triptase responsável pela ativação dos PARs é desconhecida.

As proteases de leucócitos, liberadas nos locais de inflamação, podem também servir como ativadoras dos PARs sob esta condição ${ }^{\mathbf{5 5}}$. Outras proteases importantes para ativação dos PARs são as proteases de neutrófilos. Os neutrófilos armazenam uma variedade de proteases (catepsina G, elastase, proteinase 3) nos grânulos azurófilos. A catepsina G é liberada dos neutrófilos ativados e causa agregação plaquetária. Este efeito da catepsina $\mathrm{G}$ pode ser mediado pelo PAR-4 ${ }^{\mathbf{7 9}}$. A proteinase-3, presente nos grânulos secretórios de neutrófilos e na superfície celular, também é expressa por outras células inflamatórias e age como uma protease ativadora do PAR- $2^{\mathbf{8 0}}$.

Dentre outras proteases, o FVIIa e o FXa podem também sinalizar via PARs. O FVIIa sinaliza para as células quando alostericamente associado com o fator tecidual (TF), em parte através de PAR-1 e PAR-2 ${ }^{\mathbf{8 1}}$. Similarmente o FXa solúvel ativa fracamente PAR-1, PAR-2 ou PAR-4, mas quando o FXa está associado com um complexo abrangendo TF-FVIIa-FXa, ele potencialmente ativa PAR-1 e PAR-2. O complexo TF-FVIIa-FXa cliva PAR-1 e PAR-2 numa variedade de tipos celulares, incluindo células endoteliais, que são de particular importância na inflamação ${ }^{\mathbf{8 1 , 8 2}}$ e, possivelmente, no controle do tônus vascular.

A proteína $\mathrm{C}$ ativada também foi reportada como ativadora do PAR-1 por se ligar ao receptor endotelial para a proteína $\mathrm{C}$ ativada ${ }^{\mathbf{8 3}}$, dentre diversas outras proteases agonistas dos PARs. Um resumo das principais proteases agonistas dos receptores PARs encontra-se na tabela 1.

Tabela 1 - Principais proteases agonistas dos PARs.

\begin{tabular}{cccc}
\hline PAR-1 & PAR-2 & PAR-3 & PAR-4 \\
\hline & Tripsina & & \\
Trombina & Triptase & & \\
FXa & FVIIa & & Trombina \\
PCA & MT-SP1 & Trombina & Tripsina \\
Granzima A & Proteinase-3 & & Catepsina G \\
Gingipaína-R & Acrosien & Gingipaína-R \\
Tripsina & Der P3 D9 & & \\
& Gingipaína-R & & \\
& & &
\end{tabular}

$\overline{\mathrm{FXa}}=$ Fator $\mathrm{X}$ ativado; PCA = proteína C ativada; FVIIa = fator VII ativado; MT-SP1 = serina protease-1 tipo membrana 


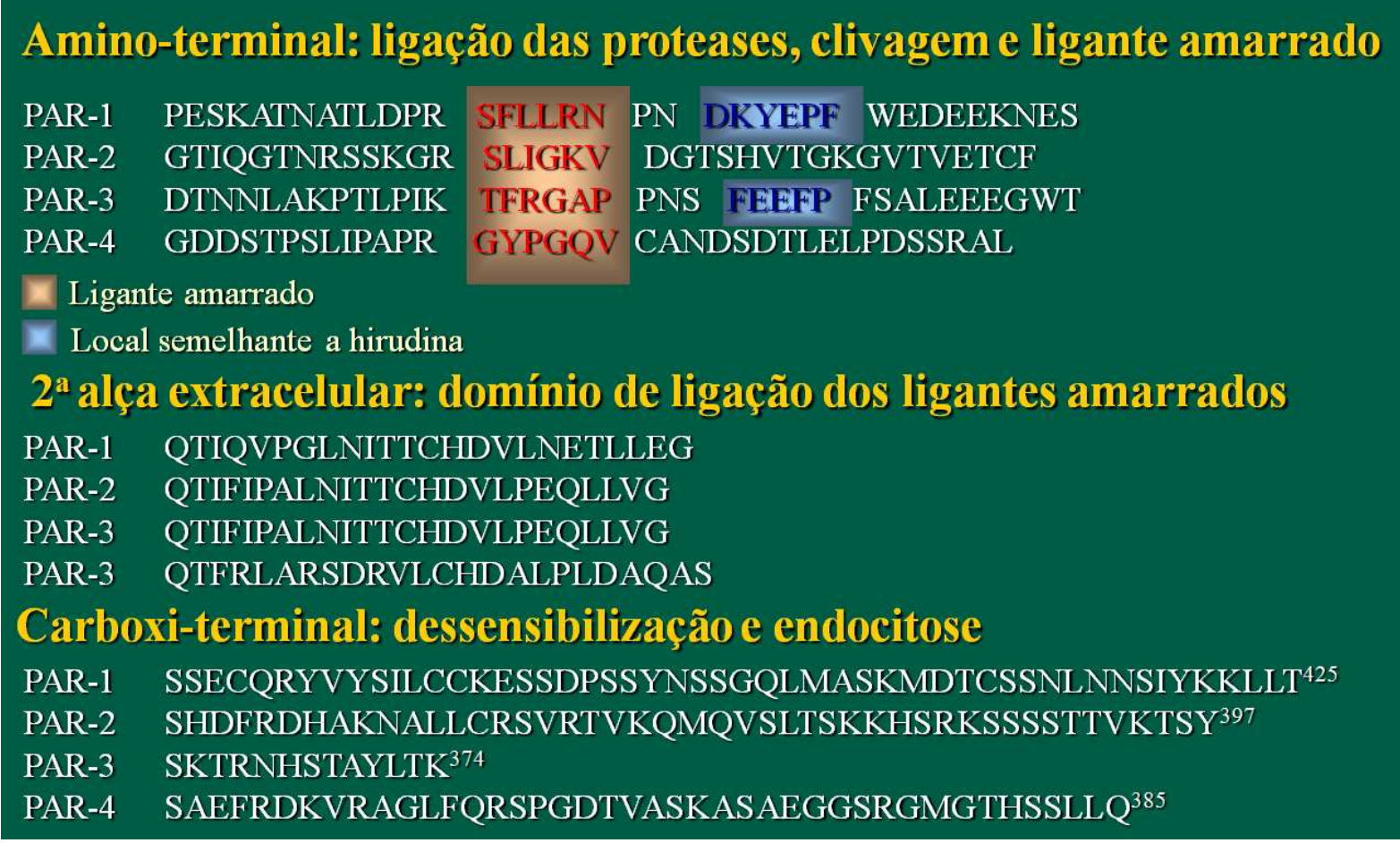

Figura 4 - Esquema representativo dos locais de ligação, clivagem, domínio de ligação e região carboxiterminal dos PARs. Para detalhes veja texto.

\subsubsection{Expressão dos PARs}

Os PARs são expressos numa ampla faixa de tecidos e tipos celulares (tabela 2). Estes incluem plaquetas, monócitos, mastócitos, linfócitos T, músculo esquelético, músculo liso vascular e não-vascular, fibroblastos, células endoteliais, células epiteliais, glândulas exócrinas, queratinócitos, osteoblastos, astrócitos e neurônios, dentre outras ${ }^{\mathbf{5 5}}$.

No sistema vascular, as células endoteliais e células do músculo liso têm um papel primário nos efeitos celulares mediados pelos $\mathrm{PARs}^{\mathbf{8 4}}$. Assim, as células endoteliais expressam PAR-1 como seu receptor predominante para a trombina. Além disso, elas também expressam PAR-2, que é ativado in vitro pela tripsina ou triptase levando às respostas similares a da trombina, como a secreção de vWF e a regulação crescente da expressão do fator tecidual ${ }^{\mathbf{8 5 , 8 6}}$. As células endotelias, também expressam pequenas quantidades de PAR$3^{87,88}$, além de expressarem PAR- $4^{\mathbf{8 9}}$ que também é ativado pela trombina.

Já as células do músculo liso vascular expressam tanto PAR-1 quanto PAR-2, que levam ao aumento do $\mathrm{Ca}^{++}$intracelular causando contração muscular ${ }^{84}$, porém há poucos relatos da expressão de PAR- $4^{\mathbf{9 0}}$ e parece não haver relatos da expressão de PAR-3 nesse tipo celular. 
Tabela 2 - Expressão celular e tecidual dos PARs.

\begin{tabular}{|c|c|c|c|}
\hline PAR-1 & PAR-2 & PAR-3 & PAR-4 \\
\hline Vasos sanguíneos & Vasos sanguíneos & Vasos sanguíneos & Vasos sanguíneos \\
\hline$\overline{\text { Endotélio vascular }}$ & $\overline{\text { Endotélio vascular }}$ & $\overline{\text { Endotélio vascular }}$ & $\overline{\text { Endotélio vascular }}$ \\
\hline Músculo liso vascular & Músculo liso vascular & & Músculo liso vascular \\
\hline Coração & Coração & Cardiomiócitos & $\underline{\text { TGI }}$ \\
\hline Cardiomiócitos & Cardiomiócitos & $\operatorname{Rim}$ & $\begin{array}{l}\text { Intestino delgado } \\
\text { Cólon }\end{array}$ \\
\hline$\underline{\operatorname{Rim}}$ & $\underline{\operatorname{Rim}}$ & & \\
\hline $\begin{array}{l}\text { Células epiteliais } \\
\text { glomerulares }\end{array}$ & $\begin{array}{l}\overline{\text { Células tubulares renais }} \\
\text { Córtex renal }\end{array}$ & $\frac{\text { Cérebro }}{\text { Astrócitos }}$ & Pâncreas \\
\hline $\begin{array}{l}\text { Células mesangiais } \\
\text { glomerulares }\end{array}$ & $\frac{\text { Cérebro }}{\text { Neurônios }}$ & $\frac{\text { Traquéia }}{\text { Músculo liso das vias }}$ & $\frac{\text { Células circulantes }}{\text { Plaquetas }}$ \\
\hline Cérebro & Astrócitos & aéreas & Megacariócitos \\
\hline$\overline{\text { Neurônios }}$ & Glia & & \\
\hline Astrócitos & & $\underline{\text { TGI }}$ & Glândula adrenal \\
\hline Glia & $\frac{\text { Traquéia/Pulmão }}{\text { Epitélio pulmonar }}$ & $\begin{array}{l}\text { Estômago } \\
\text { Intestino delgado }\end{array}$ & Pulmão \\
\hline Traquéia/Pulmão & Músculo liso brônquico & & \\
\hline $\begin{array}{l}\text { Epitélio pulmonar } \\
\text { Músculo liso das vias }\end{array}$ & Fibroblastos pulmonares & Pâncreas & $\underline{\text { Tireóide }}$ \\
\hline $\begin{array}{l}\text { Múreas } \\
\text { aéro das vias }\end{array}$ & $\underline{\text { TGI }}$ & Células circulantes & $\underline{\text { Testículo }}$ \\
\hline Fibroblastos pulmonares & $\begin{array}{l}\text { Epitélio do TGI } \\
\text { Músculo liso do TGI }\end{array}$ & Plaquetas & Próstata \\
\hline$\underline{\text { TGI }}$ & Intestino delgado & $\underline{\text { Timo }}$ & \\
\hline $\begin{array}{l}\text { Epitélio do TGI } \\
\text { Estômago }\end{array}$ & Cólon & Linfonodo & $\underline{\text { Útero }}$ \\
\hline $\begin{array}{l}\text { Cólon } \\
\text { Células circulantes } \\
\text { Plaquetas }\end{array}$ & $\begin{array}{l}\text { Pâncreas } \\
\text { Células do ducto epitelial } \\
\text { pancreático }\end{array}$ & $\underline{\text { Medula óssea }}$ & \\
\hline $\begin{array}{l}\text { Leucócitos } \\
\text { Fibroblastos } \\
\text { Mastócitos } \\
\text { Monócitos }\end{array}$ & $\begin{array}{l}\text { Células circulantes } \\
\text { Mastócito } \\
\text { Leucócito }\end{array}$ & & \\
\hline Células T & Fígado & & \\
\hline$\frac{\text { Músculo esquelético }}{\text { Miócitos }}$ & Próstata & & \\
\hline$\frac{\text { Osso }}{\text { Osteoblastos }}$ & $\frac{\text { Osso }}{\text { Osteoblastos }}$ & & \\
\hline Fibroblastos sinoviais & $\frac{\text { Glândulas }}{\text { Glândula salivar }}$ & & \\
\hline$\underline{\text { Testículos }}$ & $\begin{array}{l}\text { Glândula parótida } \\
\text { Glândula sublingual }\end{array}$ & & \\
\hline$\frac{\text { Pele }}{\text { Queratinócitos }}$ & Vesícula biliar & & \\
\hline & $\begin{array}{l}\frac{\text { Ureter }}{\text { Músculo circular do }} \\
\text { ureter }\end{array}$ & & \\
\hline & $\frac{\text { Pele }}{\text { Queratinócitos }}$ & & \\
\hline
\end{tabular}




\subsubsection{Regulação da expressão dor PARs}

O entendimento dos mecanismos que regulam a expressão dos PARs é essencial para o desenvolvimento de novas estratégias terapêuticas para a prevenção e tratamento das doenças cardiovasculares. Dentre as diversas substâncias que regulam a expressão dos receptores PARs, encontram-se substâncias químicas como citocinas, ácido lisofosfatídico e hormônios $^{\mathbf{8 9 , 9 1 - 9 7}}$. O estresse mecânico, como a lesão por balão, estresse de cisalhamento (shear stress) e estiramento cíclico (cyclic strain) também tem demonstrado causar mudanças da expressão de PARs ${ }^{\text {98-103 }}$. A aterosclerose e a hipertensão arterial também têm sido associadas com a regulação crescente (up-regulation) de PAR-1, bem como o transplante de rim e a pré-eclâmpsia ${ }^{104-108}$.

Os efeitos cardiovasculares agudos de PAR-2 possivelmente também envolvem aumento na expressão do receptor. Desse modo, tem sido mostrado que, nas células endoteliais, seguindo o pré-tratamento com lipopolissacarídeo (LPS) ${ }^{\mathbf{4}}$, ou com fator de necrose tumoral- $\alpha$ (TNF- $\alpha$ ), a expressão do receptor PAR-2 foi significativamente aumentada $^{\mathbf{8 9 , 9 4}}$. A expressão aumentada de PAR-2 também foi observada durante a reestenose seguida pela angioplastia com balão ${ }^{\mathbf{9 9}}$, indicando que a expressão aumentada do receptor pode ser uma importante característica nas ações cardiovasculares de PAR-2. Assim os efeitos dos PARs sob músculo liso tais como contração, migração, proliferação, hipertrofia e produção de matriz extracelular tornam-se dominantes em lesões vasculares contribuindo para um aumento no tônus vascular e para o desenvolvimento de lesões vasculares.

A tabela 3 resume as situações que têm sido associadas com a alteração na expressão dos PARs no sistema vascular. Ressalta-se que, em geral, a expressão dos PARs pode ser regulada no nível da transcrição, transdução, tráfego entre as membranas, endocitose e degradação lisossomal, muito embora o mecanismo molecular responsável pela mudança na expresão de PARs nas lesões vasculares ainda precise ser elucidado. Desses mecanismos de controle, a regulação transcricional parece ter papel mais importante na regulação crescente dos PARs nas lesões vasculares, porque a regulação crescente é observada em nível de RNAm 98,105. Entretanto pouco é conhecido sobre a regulação da transdução do sinal que regula a transcrição de PAR-1.

Um desses trabalhos tem demonstrado o envolvimento da proteína $G_{\alpha i}$ e da proteína quinase ativada por mitógeno (MAPK) na regulação crescente da expressão de PAR-1 em culturas de células endoteliais ${ }^{\text {91 }}$. Dessa forma, o mecanismo intracelular para a alteração transcricional dos PARs nas doenças cardiovasculares ainda permanece incerto. A 
identificação de regiões promotoras, fatores de transcrição, e sinais intracelulares de transdução, todos envolvidos nas alterações da expressão dos PARs, deverá contribuir para o entendimento da patogênese e desenvolvimento de novas estratégias para doenças cardiovasculares.

Tabela 3 - Situações associadas com alteração na expressão dos PARs.

\begin{tabular}{|c|c|c|c|c|}
\hline $\begin{array}{c}\text { Situações associadas com a } \\
\text { expressão alterada dos PARs }\end{array}$ & Mudanças na expressão & Tipo celular & $\begin{array}{c}\text { Condição } \\
\text { experimental }\end{array}$ & \\
\hline \multicolumn{5}{|l|}{ Substâncias químicas } \\
\hline Trombina & $\uparrow$ PAR-1 & $\mathrm{CEH}$ & A & 91 \\
\hline \multirow{3}{*}{$\mathrm{TNF}_{\alpha}$} & $\downarrow$ PAR-1 & $\mathrm{CEH}$ & A & 92,93 \\
\hline & $\uparrow$ PAR-2 e PAR-4 & $\mathrm{ACH}$ & A & 89 \\
\hline & & $\mathrm{CEH}$ & A & 94 \\
\hline IL- $1_{\alpha}$ & $\uparrow$ PAR-2 e PAR-4 & $\mathrm{ACH}$ & A & 89 \\
\hline IL- $1_{\beta}$ & $\uparrow$ PAR-2 & $\mathrm{CEH}$ & A & 94 \\
\hline TGF- $\beta$ & $\uparrow$ PAR-1 & MLVH e MLVR & A & 95 \\
\hline PDGF & $\uparrow$ PAR-1 & MLVH e MLVR & A & 95 \\
\hline \multirow{2}{*}{ Lipopolissacarídeo } & $\uparrow \mathrm{PAR}-2$ & $\mathrm{CEH}$ & A & 94 \\
\hline & TPAK-2 & CER & B & \\
\hline Éster de forbol & $\downarrow$ PAR-1 e PAR-2 & $\mathrm{CEH}$ & A & 94 \\
\hline Progesterona & $\uparrow$ PAR- 1 & MLAR & $A+B$ & 97 \\
\hline Dexametasona & $\uparrow$ PAR-1 & MLAR & A & 97 \\
\hline \multicolumn{5}{|l|}{ Estresse físico } \\
\hline \multirow[t]{2}{*}{ Lesão por balão } & $\uparrow$ PAR-1 & ACR & B & 98 \\
\hline & $\uparrow$ PAR-2 & ACR & B & 99 \\
\hline \multirow[t]{2}{*}{ Estresse de cisalhamento } & $\uparrow$ PAR-1 (baixo estresse) & $\mathrm{CEH}$ & A & 100,101 \\
\hline & $\downarrow$ PAR-1 (alto estresse) & MLAH & A & \\
\hline Estiramento cíclico & $\uparrow$ PAR-1 & MLAH & A & 102 \\
\hline Irradiação & $\uparrow$ PAR-1 & MLVR & B & 103 \\
\hline \multicolumn{5}{|l|}{ Condiç̃oes patológicas } \\
\hline \multicolumn{5}{|l|}{ e modelos de doenca } \\
\hline Aterosclerose & $\uparrow$ PAR-1 & MLAH & B & 104,105 \\
\hline Hipertensão induzida pela Ang II & $\uparrow$ PAR-1 & MLAR & B & 106 \\
\hline Agregação plaquetária & $\uparrow$ PAR-1 & MLVR e MLVH & A & 95 \\
\hline Pré-eclampsia & $\uparrow$ PAR-1 e PAR-2 & CEVUH & B & 107 \\
\hline Transplante de rim & $\uparrow$ PAR-1 & $\mathrm{CEH}$ & B & 108 \\
\hline
\end{tabular}

\subsubsection{Proteínas G e vias de sinalização intracelular}

As vias de transdução de sinais intracelulares têm sido intensivamente estudadas especialmente para PAR-1 ${ }^{\mathbf{5 4 , 5 5 , 1 0 9}}$. PAR-1 pode acoplar-se a $\mathrm{G}_{\alpha \mathrm{q} / 11}{ }^{\mathbf{1 1 0 - 1 1 2}}, \mathrm{G}_{\alpha \mathrm{\alpha i} / \mathrm{o}}{ }^{\mathbf{5 9 , 6 2 , 1 1 0 , 1 1 3}}, \mathrm{G}_{\alpha \mathrm{i}}$ ${ }^{112-114}$, ou $G_{\alpha 12 / 13}{ }^{115}$. A proteína $G_{\alpha q / 11}$ ativa a fosfolipase $C \beta(P L C-\beta)^{116}$, levando a produção de 3,4,5 trifosfato de inositol $\left(\mathrm{IP}_{3}\right)$ e diacilglicerol (DAG) e também induzindo a mobilização 
de $\mathrm{Ca}^{++}$e ativação da proteína quinase $\mathrm{C}(\mathrm{PKC})^{\mathbf{6 2 , 1 1 3}}$, respectivamente. $\mathrm{G}_{\alpha i / o}$ foi também sugerida estar ligada à estimulação da trombina para a mobilização de $\mathrm{Ca}^{++}$, porque a mobilização de $\mathrm{Ca}^{++}$induzida pela trombina foi inibida pela toxina pertussis em alguns tipos de células ${ }^{\mathbf{5 9 , 6 2 , 1 1 0 , 1 1 3}}$. $\mathrm{G}_{\alpha i}$ está envolvida na inibição induzida pela trombina da atividade da adenilato ciclase $\mathrm{e}^{113,114}$.

A trombina ativa também proteínas Rho e Rho-quinases via $\mathrm{G}_{\alpha 12 / 13}$ e p115 Rho GEF ${ }^{117-125}$, induzindo assim efeitos celulares como um aumento na permeabilidade endotelial ${ }^{\mathbf{1 2 6}-}$ 130 , mudanças morfológicas nas plaquetas ${ }^{\mathbf{1 2 5 , 1 3 1 - 1 3 3}}$, proliferação e migração das células do

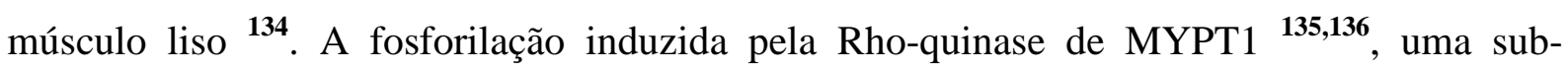
unidade regulatória da miosina fosfatase, e cadeia leve da miosina (MLC) ${ }^{\mathbf{1 3 7}}$ mostrou estar envolvida na piora da função de permeabilidade endotelial e mudança da forma das plaquetas $^{125,130,138}$. A sub-unidade $G_{\beta \gamma}$ ativa a fosfatidilinositol 3-quinase, a fosfolipase $C \beta$ (PLC- $\beta$ ), o não-receptor tirosina quinase $\mathrm{pp} 60^{\mathrm{src}}$, e a quinase do receptor acoplado a proteína $\mathrm{G}^{\mathbf{1 0 9 , 1 3 9}}$. A ativação de $\mathrm{pp} 60^{\text {src }}$ induzida pela trombina ${ }^{\mathbf{1 4 0}}$ causa a ativação da cascata da proteína quinase ativada por mitógeno via o complexo Shc-Grb2 ${ }^{\mathbf{1 4 1 - 1 4 3}}$. A ativação da proteína quinase ativada por mitógeno induzida pela trombina foi tanto sensível ${ }^{\mathbf{1 4 4}}$ quanto insensível ${ }^{\mathbf{1 4 2}}$ à toxina pertussis. $\mathrm{G}_{\alpha 12}$ também está envolvida na ativação da sinalização mitogênica mediada por $\mathrm{Shc}^{141}$.

A trombina mostrou também ativar fosfatidilinositol 3-quinase ${ }^{\mathbf{6 0 , 6 1 , 1 4 5 , 1 4 6}}$, que ativa proteínas quinases como $\mathrm{Akt} / \mathrm{PKB}^{147-150}$ e p70 ribossomal 3-quinase ${ }^{151-153}$. A ativação da fosfatidilinositol 3-quinase pode ser mediada pela associação com a sub-unidade $\mathrm{G}_{\beta \gamma}{ }^{\mathbf{1 4 5}}$ ou o

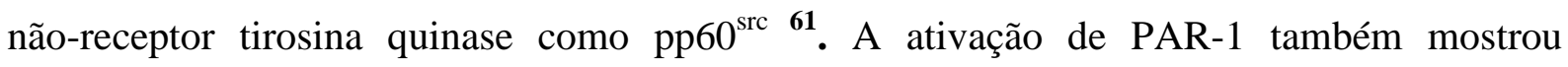
transativar o receptor EGF, que pode estar envolvido nos efeitos mitogênicos de PAR-1 ${ }^{154}$.

Em contraste ao grande número de estudos examinando a sinalização intracelular mediada pelo PAR-1, existem relativamente poucos estudos examinando as vias de sinalização para PAR-2 e muito pouco é conhecido sobre a sinalização intracelular ativada pelo PAR-3 e o PAR-4 ${ }^{\mathbf{5 5 , 1 5 5 , 1 5 6}}$. Mesmo as proteínas G acopladas a estes últimos receptores ainda precisam ser identificadas ${ }^{155}$. Assim, PAR-2 acopla-se a $G_{\alpha q / 11}$ e $G_{\alpha i / o}{ }^{155}$ ativando a PLC- $\beta$ de ambas as maneiras sensíveis e insensíveis à toxina de pertussis.

Nakayama et al. ${ }^{157}$ observaram que a tripsina induz uma elevação transitória da concentração intracelular de cálcio $\left[\mathrm{Ca}^{++}\right]_{i}$ principalmente devido à liberação de $\mathrm{Ca}^{++}$nas células endoteliais vasculares ${ }^{157}$. PAR-2 também foi reportado a ativar a proteína quinase ativada por mitógeno ${ }^{\mathbf{1 5 8 - 1 6 0}}$, proteína tirosina fosfatase $\mathrm{SHP} 2^{\mathbf{1 6 1}}$ e vias da tirosina quinase ${ }^{\mathbf{1 6 2}}$, 
que poderiam contribuir para a produção de citocinas mediadas pelo PAR-2 ${ }^{158}$, sinalização mitogênica e secreção de mucina na glândula sublingual de em $\operatorname{ratos}^{\mathbf{1 6 2}}$.

Por fim, tem sido relatado que nas células endoteliais a mobilização de $\mathrm{Ca}^{++}$mediada tanto por PAR-1 quanto por PAR-2 pode levar à liberação de NO, com consequiente vasodilatação $^{157,163}$.

\subsubsection{Regulação da sinalização dos PARs}

Como todos os outros receptores farmacológicos, os PARs podem apresentar função dual, ou seja, reconhecimento do ligante ativador e iniciação de uma resposta celular. Porém, em relação aos PARs o reconhecimento do ligante pode ser tanto para a protease ativadora quanto para o "ligante amarrado" exposto. Adicionalmente, visto que os PARs são ativados por esse "ligante amarrado" que não pode se difundir, esta família de receptores precisa também de um rápido mecanismo de desligamento/dessensibilização. Isto porque as proteases ativam os PARs por um mecanismo irreversível: a clivagem expõe o "ligante amarrado" que está sempre disponível para interagir com o receptor clivado. Assim, a ativação poderia resultar numa sinalização prolongada a menos que hajam mecanismos eficientes para atenuar a resposta.

Nesse contexto, os principais mecanismos que terminam a sinalização pelos PARs são de um modo geral similares às vias clássicas de dessensibilização que tem sido descritas em detalhes para muitos outros GPCRs, especialmente para a rodopsina e o receptor $\beta_{2^{-}}$ adrenérgico, além da inativação por proteases que clivam os PARs gerarando receptores que não são responsivos as proteases ativadoras ${ }^{\mathbf{1 6 4}}$. Um resumo desses mecansimos encontra-se na figura 5. 


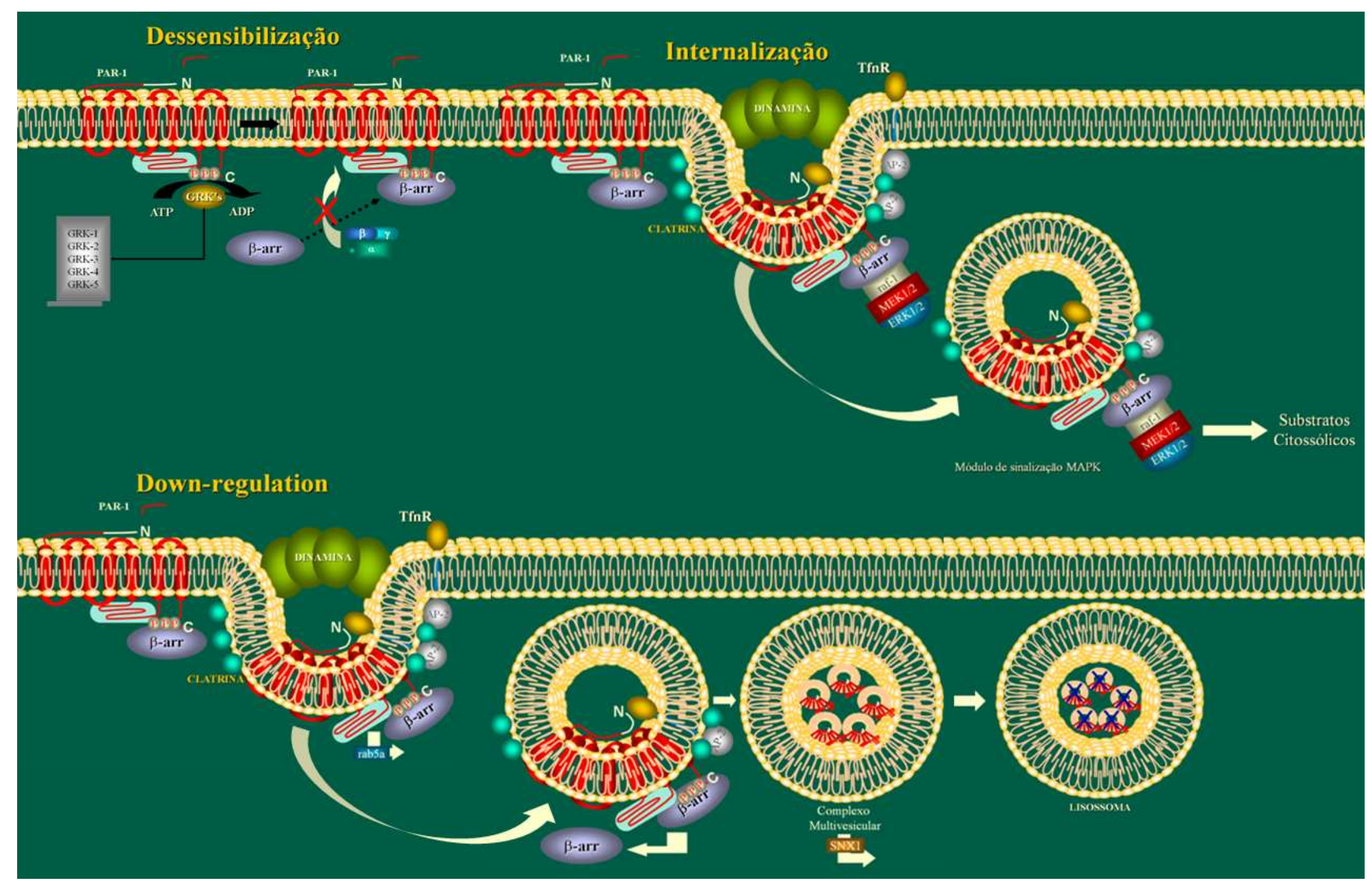

Figura 5 - Esquema repesentativo dos mecanismos de regulação da sinalização dos PARs. Para detalhes veja texto. 


\subsubsection{Inativação por proteases}

As proteases que removem ou destroem o ligante "amarrado", ou clivam o domínio de ligação na $2^{\mathrm{a}}$ alça extracelular podem gerar receptores que não são responsivos às proteases ativadoras (Figura 6). Muitas proteases podem incapacitar PARs desta maneira.

As proteases das células inflamatórias, incluindo neutrófilos e mastócitos, podem clivar e impedir a ativação dos PARs. A catepsina $\mathrm{G}$ de neutrófilos, a elastase e a proteinase-3 clivam PAR-1 para remover o local de ativação e, portanto, abolir a sinalização pela trombina ${ }^{\mathbf{1 6 5 , 1 6 6}}$. Os peptídeos ativadores do PAR-1 ainda sinalizam para as células expostas a essas proteases, sugerindo que o domínio de ligação é preservado. A quimase, uma protease abundante em mastócitos, também tornam os queratinócitos não responsivos à trombina, sugerindo que ela também inativa PAR-1 ${ }^{167}$. A elastase e catepsina G clivam PAR-2 em células transfectadas das linhagens de células epiteliais das vias aéreas, removendo os epítopos amino-terminal e, portanto gerando receptores que não são responsivos a tripsina, mas normalmente responsivos aos peptídeos agonistas do PAR-2 ${ }^{\mathbf{1 6 8}}$. Entretanto, a elastase e a catepsina $\mathrm{G}$ podem sinalizar aos fibroblastos para induzir a liberação de IL-8 e proteína-1 quimioatraente de monócitos, possivelmente pela ativação de PAR-2 ${ }^{\mathbf{1 6 9}}$. Em células transfectadas com PAR-3, a catepsina G e a elastase também podem inativar este receptor, abolindo a sinalização pela trombina ${ }^{\mathbf{1 7 0}}$.

Algumas proteases podem clivar PARs em diversos locais incluindo locais de ativação e de inativação, sendo que o resultado depende da eficiência da clivagem nos diferentes locais. Assim, embora a catepsina G possa clivar PAR-1 no local de ativação $\operatorname{Arg}^{41}-\mathrm{Ser}^{42}$, o maior local de clivagem é a $\mathrm{Phe}^{55}-\mathrm{Trp}^{56}$, que remove o ligante "amarrado" e impede a ativação do receptor ${ }^{\mathbf{1 6 5}}$. A tripsina, que tem sido reportada por ativar PAR-1, também cliva eficientemente PAR-1 no local distal, o que poderia remover o domínio do ligante “amarrado". Portanto, nas células endoteliais, a tripsina inativa PAR-1 gerando um receptor que não é responsivo a trombina ${ }^{171}$. Além da clivagem no local de ativação $\left(\operatorname{Arg}^{34}-\operatorname{Ser}^{35}\right)$, a triptase também cliva PAR-2 no local Lys ${ }^{41}-\mathrm{Val}^{42}$, o que poderia inativar o receptor ${ }^{77}$. Porém, no caso da triptase, a clivagem ativadora é mais importante, visto que a triptase ativa PAR-2. 


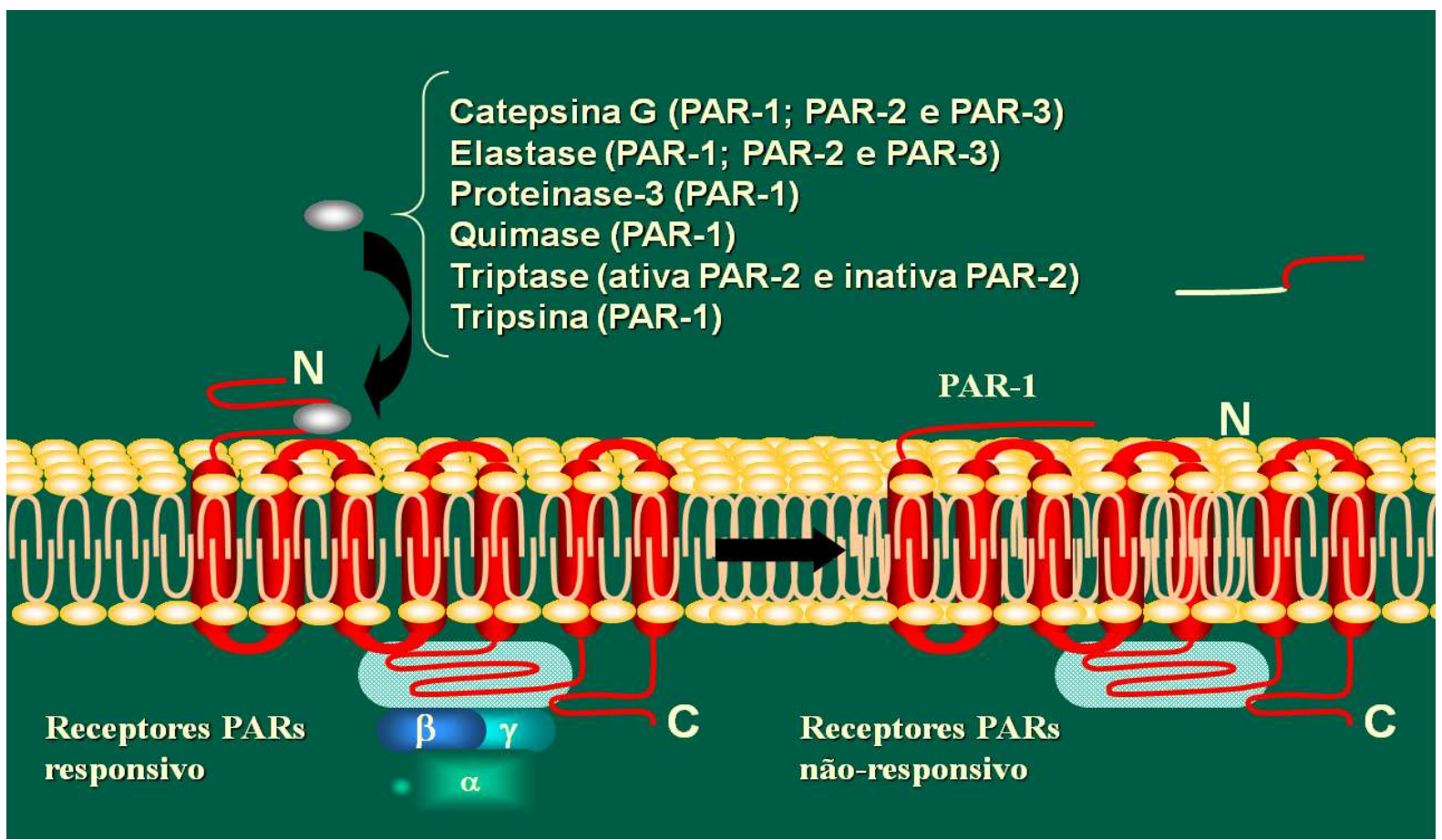

Figura 6 - Esquema representativo das proteases que inativam os PARs. Para detalhes veja texto.

\subsubsection{Dessensibilização e regulação decrescente (down-regulation)}

Como descrito anteriormente, os PARs pertencem a família dos receptores acoplados à proteína $G$, podendo ser portanto dessensibilizados. Os receptores acoplados a proteína $G$ (GPRC) são dessensibilizados inicialmente por rápida fosforilação dos receptores ativados, pela quinase de receptores acoplados a proteína G (GRKs) e outras quinases ${ }^{172}$. GRKs são serina-treonina quinases que fosforilam GPCRs ativados usualmente na região carboxiterminal ou terceira alça intracelular. A fosforilação do receptor aumenta a afinidade do receptor pelas arrestinas, e a ligação das arrestinas previne a interação receptor-proteína $G$ desacoplando assim o receptor da sinalização. Assim, um dos mecanismos importantes para terminar a sinalização de PAR-1 é a fosforilação de PAR-1 pelas GRKs ${ }^{\mathbf{5 5 , 1 7 3}}$. Experimentos de co-expressão demonstram que o PAR-1 é mais efetivamente fosforilado pela GRK-3, enquanto GRK-1 e GRK-2 têm pouco efeito ${ }^{173,174}$. GRK-2 e GRK-3 contêm um local de ligação para a sub-unidade $\mathrm{G}_{\beta \gamma}{ }^{174}$. Assim, é possível que $\mathrm{G}_{\beta \gamma}$ ativada pelo PAR-1 ative GRK3, que então fosforila e inativa PAR-1. Nesse contexto, a ativação dos PARs induz a translocação para a membrana de GRKs (GRK-3 e GRK-5 para PAR-1), que fosforilam o receptor e promovem a translocação para a membrana e a interação das $\beta$-arrestinas, mediando o desacoplamento e a dessensibilização do receptor ${ }^{164}$. Isso também é confirmado 
pelo aumento da fosforilação de PAR-1 e a marcada inibição do acúmulo de inositol fosfato, após a sobreexpressão de GRK-3 e GRK- $5^{\mathbf{1 7 3}, 175}$.

Para o PAR-2, a clivagem do receptor e a interação com a $\beta$-arrestina induz a endocitose dependente de clatrina e dinamina (uma GTPase que regula o brotamento das covas cobertas para a clatrina e em algumas células facilita a separação da caveola) ${ }^{\mathbf{1 7 6}}$, bem como o tráfego mediado por rab5a para os endossomas recentes. Os PARs são então ordenados aos lisossomas por um mecanismo envolvendo ordenação da nexina 1 (SNX1 para PAR-1). A ressensibilização requer mobilização dos "pools" intracelulares dos PARs. Os "pools" são preenchidos por uma nova síntese de PAR ou por endocitose constitutiva dos PARs inativados.

No caso do PAR-2, a ativação induz o recrutamento de $\beta$-arrestinas que servem como âncoras moleculares para recrutar e organizar os componentes da via da proteína quinase ativada por mitógeno (MAPK) para vesículas cobertas ou endossomas recentes. As $\beta$ arrestinas interagem com PAR-2, raf-1, MEK-1/2 e ERK1/2 ativada, para especificar a localização subcelular e função da ERK1/2 $\operatorname{ativada~}^{164}$.

Os processos de regulação decrescente (down-regulation) ocorrem depois de prolongada exposição ao agonista para a maioria dos GPCRs clássicos. A regulação dos níveis protéicos dos GPCRs ocorre parcialmente ao nível da transcrição e estabilidade do RNA. O tráfego dos GPCRs dos endossomas para os lisossomas é também crítico para a down-regulation ${ }^{177}$. A maioria dos GPCRs clássicos internaliza-se rapidamente, recicla-se e é regulado decrescentemente de maneira lenta. Entretanto, PAR-1 e PAR-2 ativados internalizam-se, são ordenados predominantemente aos lisossomas e rapidamente degradados.

A internalização dos GPCRs contribui para o término da sinalização por remover os receptores ativados da proteína $\mathrm{G}$ e os efetores dos sinais. Dada a natureza irreversível da ativação dos PARs, a internalização, e ordenação lisossomal dos PARs proteoliticamente ativados podem ser particularmente importantes para o término da sinalização do receptor. Em muitos casos, as arrestinas facilitam a internalização dos GPCRs por se ligarem à clatrina e $\beta_{2}$-adaptina do complexo proteína adaptadora-2 (AP-2), ligando, portanto os GPCRs à maquinaria endocítica ${ }^{178}$. Assim, a vasta maioria dos GPCRs internaliza-se através de uma via dependente de clatrina e dinamina, embora alguns GPCRs podem internalizar-se por uma via independente da dinamina ${ }^{179,180}$. 


\subsubsection{Ações vasculares dos PARs}

Até o presente momento, o papel fisiológico dos PARs no sistema cardiovascular não está completamente elucidado, principalmente porque parece haver pouca ativação de proteases com ações vasculares sob condições fisiológicas. A variedade de ações vasculares observadas é complexa e depende do leito vascular, do tamanho dos vasos, da espécie estudada, da concentração utilizada desses agonistas, da condição patológica analisada e, principalmente, do tipo celular onde os receptores são expressos.

Em relação ao leito vascular, Ku e Zaleski ${ }^{181}$ demonstraram em artérias coronárias de cães, que na presença do endotélio, tanto a trombina quanto o agonista do receptor PAR-1 (SFLLRNPNDKYEPF) produzem um potente relaxamento dependente da dose, enquanto que em artérias coronárias com o endotélio desnudado esse peptídeo produz uma potente contração dependente da dose. Em contranste, Tesfamariam ${ }^{\mathbf{1 8 2}}$ demonstrou que, em cães, a $\alpha$ trombina causa contração das artérias coronárias com o endotélio intacto, caracterizada por um relaxamento transitório seguido por um lento desenvolvimento de contrações sustentadas. Essas ações da $\alpha$-trombina foram mimetizadas pelo peptídeo SFLLRNP, que ativa o receptor da trombina. Entretanto, diferentemente do observado com este peptídeo, as contrações induzidas pela $\alpha$-trombina foram bloqueadas pela hirudina (um inibidor específico da trombina), nifedipina e diltiazen (bloqueadores dos canais para $\mathrm{Ca}^{++}$), ou estaurosporina e calfostina $\mathrm{C}$ (inibidores da proteína quinase $\mathrm{C}$ ) ${ }^{\mathbf{1 8 2}}$. Esses efeitos contráteis da ativação de PAR-1 nos vasos coronários podem também mediar mudanças secundárias na função cardíaca, como diminuição no débito cardíaco e pressão arterial média ${ }^{\mathbf{1 8 3}}$, além do fato de que a trombina pode estimular ambos diretamente, através de um efeito inotrópico positivo pelo aumento de $\mathrm{Ca}^{++}$intracelular ${ }^{184}$.

Em relação às artérias coronárias de porcos e humanos, alguns autores têm demonstrado que a ativação de PAR-1 também induz um relaxamento dependente do endotélio, porém sem efeito contrátil direto no músculo liso ${ }^{\mathbf{1 6 3 , 1 8 5}}$. Por exemplo, Hamilton e Cocks $^{186}$ investigaram os mecanismos de relaxamento induzido pelo PAR-1 e PAR-2 em anéis de artéria coronária de porcos. Eles demonstraram que inibidores dos canais para $\mathrm{Ca}^{++}$ operados por voltagem do tipo L (L-VOCC) como a nifedipina bloqueiam seletivamente o componente não mediado pelo NO do relaxamento dependente do endotélio, para concentrações fisiológicas de trombina em artérias coronárias de porco, mas não para peptídeos ativadores de PAR-1 (SFLLRN), de PAR-2 (SLIGRL) ou tripsina. Esses resultados 
sugerem um mecanismo heterogêneo no relaxamento independente do NO para a trombina e peptídeos ativadores de PAR-1 em artérias coronárias de porco ${ }^{\mathbf{1 8 6}}$.

Em humanos, esses autores demonstraram que a trombina, o peptídeo agonista do receptor PAR-1 (SFLLRN-NH ${ }_{2}$ ) e a tripsina causaram relaxamento dependente do endotélio em anéis de artéria coronária humana, o que quase não foi observado com o peptídeo agonista de PAR-2 (SLIGKV-NH $\left.{ }_{2}\right)^{186}$. Outros autores têm demonstrado que em "strips" isolados de artérias coronárias humanas normais, a estimulação de PAR-1 induz relaxamento independente do endotélio, sem induzir qualquer contração ${ }^{\mathbf{1 0 4}}$.

De um modo geral, em aortas isoladas de diversas espécies como rato, cobaia e cachorro a trombina e os TRAPs medeiam, um substancial relaxamento dependente do endotélio $^{104,187-189}$. Este relaxamento é comumente mediado pela liberação de produtos da COX (incluindo possivelmente $\mathrm{PGI}_{2}$ ) e por $\mathrm{NO}$, porque muitas das repostas podem ser revertidas por indometacina e L-NAME ou análogos relacionados ${ }^{104,189}$. Seguindo a remoção do endotélio, a trombina, em algumas preparações, gera forte resposta contrátil ${ }^{\mathbf{1 0 4 , 1 8 9}}$, consistente com a expressão de PAR-1 ligado ao influxo de $\mathrm{Ca}^{++}$no músculo liso subjacente ${ }^{190-192}$. Assim, alguns autores têm demonstrado que em aorta de cobaias e aortas de coelho, a trombina contrai diretamente o músculo liso ${ }^{\mathbf{1 0 4 , 1 8 1 , 1 8 7 , 1 9 3}}$.

De forma semelhante, Antonaccio et al. ${ }^{191}$, examinando o papel do receptor da trombina em anéis aórticos isolados, demonstraram que os peptídeos que ativam o receptor da trombina SFLLRNPNDKYEPF $\left(\right.$ TRAP $\left._{1-14}\right)$, SFLLRNP $\left(\right.$ TRAP $\left._{1-7}\right)$ e SFFLRNP $\left(\right.$ TRAP $_{1-7}$ para ratos) causaram contrações dependentes das doses em anéis de aorta com o endotélio desnudado. Eles demonstraram ainda que as contrações causadas pelos TRAPs foram substancialmente reduzidas, mas ainda estavam presentes, em anéis com o endotélio intacto devido a liberação do de NO, já que a redução das contrações foi revertida por $\mathrm{N}^{\omega}$-nitro-Larginina ou pelo azul de metileno. A contração induzida por esses peptídeos não foi afetada pela incubação desses anéis com alta concentração do inibidor da $\alpha$-trombina (MD-805), antagonista do receptor $\mathrm{ET}_{\mathrm{A}}(\mathrm{BQ}-123)$, antagonista do receptor de tromboxano (SQ29584) ou inibidor da cicloxigenase (indometacina), embora a pré-incubação com antagonista do receptor $\alpha_{1}$-adrenérgico (prazosina) causou um aumento relativamente pequeno da resposta máxima ao $\mathrm{TRAP}_{1-7}$ na maior concentração utilizada deste peptídeo. Entretanto, o prétratamento com nifedipina ou a remoção do $\mathrm{Ca}^{++}$reduziram marcadamente essa resposta contrátil. Em contraste, a aorta isolada de ratos não contraiu em resposta a $\alpha$-trombina humana ou de rato ${ }^{191}$. De outro modo, diversos autores não foram capazes de observar qualquer contração para trombina nos "strips" mediais de aortas de ratos, embora tenha induzido um 
aumento na concentração citossólica de $\mathrm{Ca}^{++}$em cultura de células do músculo liso derivadas de aortas de $\operatorname{ratos}^{84}$.

$\mathrm{Na}$ artéria renal interlobal de porcos, a trombina induziu resposta bifásica no tônus vascular, consistindo de relaxamento dependente do endotélio, seguido por contração dependente do endotélio ${ }^{194}$. Em artérias renais de humanos, Tognetto et al. ${ }^{\mathbf{1 9 5}}$ demonstraram a expressão e as funções motoras do receptor PAR-1 e propuseram um possível papel deste receptor para a homeostase vascular. Assim, a trombina, o peptídeo ativador de PAR-1 (SFLLRN-NH ${ }_{2}$, mas não o peptídeo reverso (NRLLFS-NH $\mathrm{NH}_{2}$ ) contraíram ambos "strips" de artéria renal humana com o endotélio intacto e desnudado, enquanto nenhum relaxamento foi observado em cada "strip" sem pré-contração ou pré-contraído com fenilefrina. A contração máxima para a trombina ou SFLLRN-NH $\mathrm{N}_{2}$ foi cerca de $60 \%$ daquela induzida pela fenilefrina. Entretanto, a trombina foi aproximadamente 1000 vezes mais potente do que SFLLRN-NH ${ }_{2}$. Ressalta-se que esse efeito contrátil produzido pela trombina e SFLLRN-NH ${ }_{2}$ não foi afetado pela inibição da NOS, mas foi significantemente reduzido pelo bloqueio da COX e que, a desensibilização do receptor PAR-1, usando repetidas aplicações de SFLLRN$\mathrm{NH}_{2}$ também bloqueou, quase que completamente, a resposta à trombina ${ }^{\mathbf{1 9 5}}$.

Em outros vasos, como por exemplo, as artérias da placenta e umbilical humana, a resposta contrátil pode prevalecer mesmo com o endotélio intacto ${ }^{196}$, indicando diferenças na expressão relativa e função do PAR-1 nas células endoteliais e do músculo liso em diferentes vasos. Essas diferenças são refletidas em respostas de todo o órgão para a ativação de PAR-1: a administração de TRAPs causa vasodilatação no pulmão perfundido de porcos, mas vasoconstrição no pulmão de cobaias ${ }^{197,198}$. Outros autores têm ainda demonstrado que a trombina não apresenta efeito contrátil direto em artérias mesentéricas e femorais de coelhos, enquanto que, em altas concentrações, causa apenas pouca contração das artérias basilar dessa espécie $^{\mathbf{8 4}}$. Como resultado, as células endoteliais são consideradas as células primárias que medeiam os efeitos vasculares dos PARs ${ }^{199}$.

Numerosos estudos têm também demonstrado que a tripsina e os peptídeos agonistas de PAR-2 (PAR-2 APs) causam relaxamento dependente do endotélio de preparações isoladas de rato $^{200}$, e aorta de coelho ${ }^{201}$, coronária de porco $^{202,203}$, e artéria basilar ${ }^{204,205}$, bem como em humanos in vivo; e que a vasoconstrição tem sido observada seguindo a desnudação do endotélio em algumas preparações, como aorta de coelho ${ }^{206}$, e seus correlatos, com expressão de PAR-2 na camada do músculo liso dessas espécies. Os inibidores do NO revertem o relaxamento mediado pelo PAR-2 na grande maioria dessas preparações, o que é consistente com um papel para o NO como intermediário dessa resposta. As pesquisas sugerem que isto é 
um resultado direto da mobilização de $\mathrm{Ca}^{++}$induzida pelo PAR-2 e subseqüente ativação da eNOS. Tem-se ainda demonstrado que, em aorta de rato, a liberação de NO induzida por SLIGRL é inibida pelo antagonista do receptor B da endotelina (BQ-788), sugerindo que a ET-1 age como um intermediário nesta resposta ${ }^{207}$.

Em artérias cerebrais in vivo, Sobey e Cocks ${ }^{204}$ demonstraram que a ativação de PAR2 resulta em potente resposta vasodilatadora, mediada pela produção de NO derivado do endotélio $^{204}$.

Em arteríolas aferentes renais, Trottier et al $^{\mathbf{2 0 8}}$ demonstraram que a ativação de PAR-2 promove vasodilatação por mecanismos dependentes e independentes do NO. Este último envolve uma resposta como a do EDHF, a qual é prevenida pela elevação do potássio externo. Esses achados sugerem que a ativação, pela protease, do PAR-2 microvascular renal poderia resultar em vasodilatação renal $^{\mathbf{2 0 8}}$. Entretanto, Tognetto et al. ${ }^{\mathbf{1 9 5}}$ demonstraram que, em artérias renais de humanos, a tripsina, os peptídeos ativadores do PAR-2 (SLIGKV-NH $\mathrm{NH}_{2}$ e SLIGRL-NH ${ }_{2}$ ) e PAR-4 (GYPGQV-NH 2 e AYPGKF- $\mathrm{NH}_{2}$ ) não produziram qualquer contração ou relaxamento significante ${ }^{195}$.

Em arteríolas mesentéricas de camundongo, McGuire et al. ${ }^{\mathbf{2 0 9}}$ demonstraram que o relaxamento mediado pelo PAR-2 utilizam múltiplos mecanismos que são ambos, dependente e independente do NO-GMPc. Os dados também são consistentes com um papel para a hiperpolarização dependente do endotélio do músculo liso vascular que envolve a ativação de um canal para $\mathrm{K}^{+}$sensível a apamina/caribdotoxina e, em parte, podem ser mediados pelo $\mathrm{K}^{+}$. Foi concluído, ainda neste detalhado estudo, que o citocromo P450, COX, adenilato ciclase (AC), um mecanismo mediado por neurônios, comunicações por junções " $g a p$ " intercelular ou um efeito residual do NO não contribuem para o relaxamento não-mediado pelo NO. Também não houve evidência de uma ativação de PARs indiretamente, ao menos através da ativação de $\mathrm{NK}_{1} / \mathrm{NK}_{2}, \mathrm{~B}_{2}, \mathrm{H}_{1 / 2}$ ou receptores $\beta$-adrenérgicos, mediando o relaxamento, embora a liberação de $\mathrm{K}^{+}$endotelial e a ativação de $\mathrm{K}_{\text {ir }}$ e $\mathrm{Na}^{+} / \mathrm{K}^{+}$ATPase possam contribuir para o relaxamento. As características do relaxamento são consistentes com mecanismos mediados pelo EDHF, e indicam uma dependência na ativação de um canal para $\mathrm{K}^{+}$ativado por cálcio sensível a apamina/caribdotoxina. Entretanto estudos eletrofisiológicos serão requeridos para elucidar o potencial mecanismo de hiperpolarização do músculo liso vascular $^{209}$.

Outros estudos como o de Robin et al. ${ }^{\mathbf{2 1 0}}$, utilizando a técnica de pletismografia da veia dorsal da mão e do antebraço tem ainda demonstrado que a ativação de PAR-2 por 
SLIGKV-NH $\mathrm{NH}_{2}$ causa dilatação venosa e arterial em humanos in vivo e que os efeitos são reduzidos pela inibição da síntese de NO ou prostaglandina.

A resposta vascular para a ativação dos receptores PARs parece também ser dependente do diâmetro vascular. Foi demonstrado por Hamilton et al. ${ }^{\mathbf{2 1 1}}$ que a trombina, a tripsina e o peptídeo agonista do receptor PAR-1 (TFLLR) causaram relaxamento dependente da concentração em grandes (epicárdica $\approx 2 \mathrm{~mm}$ de diâmetro interno) e pequenas (intramiocárdica $\approx 200 \mu \mathrm{m}$ de diâmetro interno) artérias coronárias humanas. Nesse estudo, os valores de $\mathrm{EC}_{50}$ para a trombina e tripsina foram significativamente maiores nas artérias intramiocárdicas. Em contraste, não houve diferença para peptídeo agonista do receptor PAR1 (TFLLR) entre as artérias coronárias epicárdicas e intramiocárdicas.

Ao analisarem as artérias coronárias de porcos os valores de $\mathrm{EC}_{50}$ para o relaxamento causado pela trombina também foi significativamente maior em artérias menores. Entretanto, não foram diferentes para TFLLR e para o peptídeo agonista de PAR-2 (SLIGKV) entre os dois ramos das coronárias analisados. Isto indica que a ativação dos receptores PARs é dependente do diâmetro em artérias coronárias isoladas de porcos e de humanos, e sugere aumento na regulação da resposta vascular mediada pelos PARs em artérias semelhantes às de resistência ${ }^{211}$.

A ativação dos receptores PARs varia ainda com a concentração do agonista utilizado. Por exemplo, alguns trabalhos têm demonstrado que em altas concentrações a $\alpha$-trombina causa contrações que são inibidas por inibidores do receptor $\alpha$-adrenérgico e síntese de prostaglandinas em artéria basilar de cães e femoral de coelhos ${ }^{\mathbf{2 1 2}-214}$, embora outros autores têm demonstrado que esses inibidores não tem efeito nas contrações induzidas pela $\alpha$ trombina na coronária de cães e aorta de coelhos, indicando a ausência de um papel envolvendo receptores $\alpha$-adrenérgicos e prostaglandinas na mediação das contrações. Entretanto, em baixas concentrações, a $\alpha$-trombina tem mostrado induzir relaxamento dependente do endotélio na artéria aorta, cerebral, femoral, coronárias e na veia safena de várias espécies, incluindo cães e porcos ${ }^{181,215-218}$.

Estudos recentes também têm mostrado que a tripsina e altas concentrações de PAR2APs podem também iniciar contrações dependentes do endotélio tanto em artéria de pulmonar de ratos ${ }^{201}$ quanto em veia umbilical humana ${ }^{219}$, possivelmente através da liberação de um fator contrátil não identificado das células endoteliais humanas. Esta resposta parece ser mediada através de um novo subtipo de PAR-2.

É concebível ainda que os efeitos vasculares das proteases, e conseqüentemente o papel dos PARs, sejam mais relevantes em condições patológicas, visto que as proteases no 
sistema de coagulação-fibrinólise e outras proteases, incluindo àquelas derivadas de células imunes e inflamatórias, são ativadas em condições patológicas, como a formação de trombo, hemorragia, inflamação, ou lesão tecidual as quais, juntamente com o estresse oxidativo, vem sendo relacionados ao dano endotelial presente na hipertensão essencial ${ }^{\mathbf{2 2 0}}$.

Por fim, as ações vasculares dos PARs variam em relação ao tipo celular. Assim, nas células endoteliais a ativação de PAR-1 contribui para o relaxamento dependente do endotélio ou contrações dependentes do endotélio, dependendo do tipo de vaso sanguíneo ${ }^{\mathbf{5 5 , 2 2 1 - 2 2 6}}$. Contribui ainda para a angiogênese $\mathrm{e}^{\mathbf{1 0 9 , 2 2 1}}$ além de causar alteração na expressão de múltiplos genes como de citocinas, quimiocinas e moléculas de adesão.

Já no músculo liso vascular, PAR-1 medeia a contração, migração celular, proliferação, hipertrofia e produção da matriz extracelular ${ }^{222}$. Similarmente, PAR-2 também medeia o relaxamento dependente do endotélio e angiogênese nas células endoteliais, e medeia a contração, migração celular, hipertrofia e produção da matriz extracelular nas células do músculo liso. PAR-3 age como um co-fator para PAR-4, não desencadeando sinais intracelulares ${ }^{109,227}$. Este, por sua vez também tem demonstrado induzir a produção NO nas células endoteliais $^{\mathbf{2 2 8}}$ e relaxamento dependente do endotélio ${ }^{\mathbf{2 2 9}-231}$, embora seu papel nas células do músculo liso permaneça deconhecido. Dessa forma, os PARs têm mostrado regular o tônus vascular e a permeabilidade, proliferação e hipertrofia das células vasculares, angiogênese, bem como desenvolvimento do sistema vascular ${ }^{222}$, o que torna de grande importância o estudo desses receptores em doenças cardiovasculares como é o caso da hipertensão arterial.

Além dos efeitos agudos sobre o tônus vascular, tanto PAR-1 quanto PAR-2, estão fortemente implicados na resposta crônica associada à inflamação dos vasos e cicatrização de feridas $^{55}$. Nesse contexto, a trombina tem mostrado regular crescentemente, ou regular decrescentemente a expressão de múltiplos genes em culturas de células endoteliais ${ }^{\mathbf{2 3 2}, 233}$. A expressão dos genes relacionados à angiogênese e crescimento celular (receptor para o fator de crescimento endotelial vascular, angiopoietina, fatores de crescimento derivados de plaquetas), hemostasia [(fator tecidual, inibidor do ativador do plasminogênio (PAI-1), citocinas e quimiocinas (interleucina-6 e 8, proteína-1 quimioatraente de monócitos)] e adesão celular (VCAM-1, ICAM-1, E-selectina) tem mostrado ser reguladas crescentemente pela trombina $^{232}$.

Essas alterações de expressão gênica podem estar ligadas à conversão fenotípica das células endoteliais para o fenótipo pró-inflamatório. É possível que tal conversão fenotípica, observada em cultura de células endoteliais, possa ter um papel chave no estágio recente do 
desenvolvimento da lesão vascular. Entretanto, esta possibilidade ainda precisa ser elucidada in vivo, já que os PARs parecem ter um pequeno papel na resposta inflamatória da endotoxemia experimental $^{234}$.

A tripsina e PAR-2 APs também estão envolvidos na resposta inflamatória. Assim, a tripsina e PAR-2 APs estimulam a ativação de células $\mathrm{T}$ e neutrófilos e promovem o rolamento e a adesão de leucócitos ${ }^{\mathbf{2 3 5 , 2 3 6}}$.

Nesse sentido, Vergnolle ${ }^{236}$ demonstrou que os peptídeos $\mathrm{SL}_{-} \mathrm{NH}_{2}$ e trans-cinamoilLIGRLO-NH ${ }_{2}\left(\mathrm{Tc}-\mathrm{NH}_{2}\right)$, que ativam especifica e seletivamente PAR-2, podem contribuir para diversos eventos na reação inflamatória, incluindo rolamento de leucócitos, aderência e recrutamento, por um mecanismo independente da ativação de mastócitos e dependente da liberação do fator ativador de plaquetas (PAF) ${ }^{\mathbf{2 3 6}}$. PAR-2 também promove o extravasamento de leucócitos in vivo, que é facilitado pela permeabilidade capilar aumentada e produção aumentada de citocinas. Ele também está ligado a produção aumentada do fator de Von Willenbrand, crescimento do músculo liso e célula endotelial, e aumento no RNAm e atividade do fator tecidual $^{\mathbf{8 6 , 2 3 7 - 2 3 8}}$, todas respostas relevantes aos aspectos da cicatrização de feridas. Já que diversas respostas cardiovasculares, incluindo a cicatrização de feridas, envolvem a inflamação, ainda não está claro se a ativação de PAR-2 dessas respostas é parte de da fisiologia normal dos vasos ou associada com o desenvolvimento de certas doenças cardiovasculares. Estudos adicionais são requeridos para elucidar esses pontos. 


\section{CONCLUSÃO}

$\mathrm{Na}$ hipertensão arterial primária observa-se reduzido relaxamento dependente do endotélio decorrente de menor biodisponibilidade do NO, resultado tanto do aumento do estresse oxidativo, quanto da liberação aumentada de EDCF's como endoperóxidos e tromboxanos, EROs e/ou ET-1 pelo endotélio vascular ${ }^{30}$. A este desequilíbrio na produção endotelial de mediadores que regulam o tônus vascular, agregação plaquetária, coagulação e fibrinólise, denominamos disfunção endotelial.

Nosso trabalho é um dos primeiros a demonstrar o papel dos receptores ativados por protease (PARs) na alteração da resposta vascular observada na hipertensão arterial. Nós demonstramos que a ativação de PAR-1, encontra-se alterada em animais hipertensos (SHR) onde observamos vasoconstrição dependente e independente do endotélio vascular. Nossos resultados indicam que a aorta de animais hipertensos (SHR) apresenta importante disfunção endotelial caracterizada por um significativo aumento na vasoconstrição induzida pelo peptídeo agonista do receptor PAR-1 (TFLLR-NH ${ }_{2}$ ).

Nós aventamos a hipótese de que esta disfunção endotelial poderia estar relacionada à maior liberação de EDCF's pelas células endoteliais e/ou aumento da expressão gênica/protéica de PAR-1 em animais SHR. Concluímos que ambos estão presentes, ou seja, ocorre maior expressão gênica/protéica no leito vascular mesentérico, bem como maior expressão gênica na aorta de animais hipertensos, além de haver ainda aumento na liberação de Ang II, ET-1 e $\mathrm{O}_{2}^{-}$pela aorta com endotélio estimulada peptídeo agonista do receptor PAR-1 (TFLLR-NH ${ }_{2}$ ), em animais hipertensos, caracterizando dessa forma a disfunção endotelial observada. Nesse caso, os canais para $\mathrm{Ca}^{++}$sensível a voltagem do tipo L também estão envolvidos. Entretanto, ressaltamos que os mecanismos intracelulares responsáveis pela liberação desses EDCFs, após a estimulação do peptídeo agonista do receptor PAR-1 (TFLLR-NH ${ }_{2}$ ) ainda precisam ser esclarecidos.

Outro aspecto importante de nosso trabalho é a observação da vasomotilidade in vivo mediada pela estimulação de PAR-1 e PAR-2, a qual acreditamos ser os primeiros a descrevêla. Este fenômeno tem sido amplamente relacionado à hipertensão arterial e parece ser importante para melhorar a rarefação capilar observada na vasculatura hipertensa pela entrega de oxigênio proveniente da vasomotilidade.

Analisando todos esses resultados, concluímos que o receptor PAR-1 é o principal receptor envolvido na alteração da reatividade vascular observada na hipertensão, em 
comparação aos outros receptores ativados por protease (PAR-2, PAR-3 e PAR-4), que parecem não participar de tal fato.

Dessa forma, acreditamos que esse receptor poderia representar um novo alvo terapêutico para fármacos anti-hipertensivos, que poderiam apresentar benefícios adicionais em reduzir o estado hipercoagulável presente na hipertensão arterial já que, além do seu envolvimento no controle do tônus vascular, este receptor têm sido amplamente relacionado à fenômenos tromboembólicos. 


\section{REFERÊNCIAS BIBLIOGRÁFICAS ${ }^{*}$}

1 World Health Organization - International Society of Hypertension Guidelines for the Management of Hypertension: Guidelines Subcommittee. J. Hypertens., v. 17, n. 2, p. 151183, 1999.

2 HAMMOND, J. W. et al. Relation of blood pressure and body build to left ventricular mass in termotensive and hypertensive employed adults. J. Am. Coll. Cardiol., v. 12, p. 9961004, 1988.

3 LEVY, D. et al. Echocardiographically detected left ventricular hypertrophy: prevalence and risk factors. Ann. Intern. Med., v. 108, p. 7-13, 1989.

4 HOUGHTON, J. L. et al. Relations among impaired coronary flow reserve, left ventricular hypertrtophyand thallium perfusion defects in hypertensive patients without obstructive coronary artery disease. J. Am. Coll. Cardiol., v. 13, p. 43-51, 1990.

5 BRILLA, C. G. et al. Remodeling of the rat right and left ventricles in experimental hipertensión. Circ. Res., v. 67, p. 1355-1364, 1990.

6 LEVY, D. et al. Prognostic implications of echocardiographically determined left ventricular mass in the Framingham Heart Study. N. Engl. J. Med., v. 332, p. 1561-1566, 1990.

7 JOINT NATIONAL COMMITTEE ON PREVENTION, DETECTION, EVALUATION, AND TREATMENT OF HIGH BLOOD PRESSURE. The Sixth Report of the Joint National Committee on Prevention, Detection, Evaluation, and Treatment of High Blood Pressure. Arch. Intern. Med., v. 157, p. 2413-2446, 1997.

8 FREITAS, O. C. et al. Prevalence of hypertension in the urban population of Catanduva, in the State of Sao Paulo, Brazil. Arq. Bras. Cardiol., v. 77, n. 1, p. 9-21, 2001

9 FUCHS, F. D. et al. Prevalência de hipertensão arterial sistêmica e fatores associados na região urbana de Porto Alegre: estudo de base populacional. Arq. Bras. Cardiol., v. 63; p. 473-479, 1995.

10 LOLIO, C. A. Prevalência de hipertensão arterial em Araraquara. Arq. Bras. Cardiol., n. 55, p. 167-173, 1990.

11 MARTINS, I. S. et al. Doenças cardiovasculares ateroscleróticas, dislipidemias, hipertensão, obesidade e diabete melito em população da área metropolitana da região Sudeste do Brasil. III - Hipertensão. Rev. Saúde Pública, v. 31, n. 5, p. 466-471, 1997.

\footnotetext{
* De acordo com:

ASSOCIAÇÃO BRASILEIRA DE NORMAS TÉCNICAS. NBR 6023: Informação e documentação: referências: elaboração. Rio de Janeiro, 2002.
} 
12 REGO, R. A. et al. Risk factors for chronic non-communicable diseases: a domiciliary survey in the municipality of Sao Paulo, SP (Brazil). Methodology and preliminary results. Rev. Saúde Pública, v. 24, n. 4, p. 277-285, 1990.

13 AYRES, J. E. Prevalence of hypertension in the city of Piracicaba. Arq. Bras. Cardiol., v. 57, p. 33-36, 1991.

14 LESSA, I. Epidemiologia da hipertensão arterial sistêmica e da insuficiência cardíaca no Brasil. Rev. Bras. Hipertens., v. 8, n. 4, p. 383-392, 2001.

15 SHOEN, F. J. Vasos sanguíneos. In.: ROBBINS, S. L. et al. Patologia Estrutural e Funcional. Rio de Janeiro: Guanabara Koogan, 1996, cap. 11, p. 414-456.

16 COLLINS, R. et al. Blood pressure, stroke, and coronary heart disease, part 2: shortterm reductions in blood pressure: overview of randomised drug trials in their epidemiological context. Lancet., v. 335, p. 827-838, 1990.

17 ROSTAND, S. G. et al. Renal insufficiency in treated essential hypertension. N. Engl. J. Med., v. 320, n. 11, p. 684-688, 1989.

18 KANNEL, W. B. Implications of the primary prevention trials against coronary heart disease. J. Hypertens Suppl., v. 8, n. 7, p. S245-S250, 1990.

19 LIP, G. Y. H.; LI-SAW-HEE, F. L. Does hypertension confer a hypercoagulable state? J. Hypertens., v. 16, p. 913-916, 1998.

20 BATlOUNI, M.; RAMIRES, J. A. F. Endotélio e Cardiologia. In: CASTRO, I. Cardiologia: princípios e prática. São Paulo: Artes Médicas Sul Ltda., 1999. cap. 5, p. 191205.

21 FURCHGOTT, R. F.; ZAWADZKI J., V. The obligatory role of endothelial cells in the relaxation of arterial smooth muscle by acetylcholine. Nature., v. 288, n. 5789, p. 373$376,1980$.

22 CARVALHO, MHC et al. Funções normais do endotélio - Uma visão geral. In.: LUZ, P. L.; LAURINDO, F. R. M.; CHAGAS, A. C. P. Endotélio \& doenças cardiovasculares. São Paulo: Atheneu, 2003. p. 17-32.

23 COLAÇO, A. L. et al. Participação do endotélio vascular. In.: BRANDÃO, A. A.; AMODEO, C.; NOBRE, F.; FUCHS, F. D. Hipertensão. Rio de Janeiro: Elsevier, 2006. p. 76-85.

24 VAPAATALO $\mathrm{H}$; MERVAALA E. Clinically important factors influencing endothelial function. Med. Sci. Monit., v. 7, p. 1075-1085, 2001.

25 CARVALHO, M. H. C. et al. Hipertensão arterial: o endotélio e suas múltiplas funções. Rev. Bras. Hipertens., v. 8, p. 76-88, 2001.

26 VANHOUTTE, P. M. Endothelial dysfunction in hypertension. J. Hypertens. Suppl., v. 14, n. 5, p. S83-S93, 1996. 
27 CARVALHO, M. H. C. et al. Reactivity of aorta and mesenteric microvessels to drugs in spontaneously hypertensive rats: role of the endothelium. J. Hypertens., v. 5, p. 377-382, 1987.

28 PANZA, J. A. et al. Impaired endothelium-dependent vasodilation in patients with essential hypertension: evidence that the abnormality is not at the muscarinic receptor level. $\mathbf{J}$. Am. Coll. Cardiol., v. 23, n. 7, p. 1610-1616, 1994.

29 PANZA, J. A. et al. Impaired endothelium-dependent vasodilation in patients with essential hypertension. Evidence that nitric oxide abnormality is not localized to a single signal transduction pathway. Circulation., v. 91, n. 6, p. 1732-1738, 1995.

30 SCHIFFRIN, E. L. A Critical Review of the Role of Endothelial Factors in the Pathogenesis of Hypertension. J. Cardiovasc. Pharmacol., v. 38, (Suppl. 2), f p. S3-S6, 2001.

31 MOMBOULI, J.; VANHOUTE, P. M. Endothelial Dysfunction: From Physiology to Therapy. J. Mol. Cell. Cardiol., v. 31, p. 61-74, 1999.

32 KAKAR, P.; LIP, G. Y. Hypertension: endothelial dysfunction, the prothrombotic state and antithrombotic therapy. Expert. Rev. Cardiovasc. Ther., v. 5, n. 3, p. 441-450, 2007.

33 LIP, G. Y. Hypertension (or "Birmingham Paradox") Revisited Hypertension, Platelets, and the Endothelium: The "Thrombotic Paradox" Hypertension., v. 41, p. 199-200, 2003.

34 VIRCHOW, R. Phlogose und Thrombose im Geraßsystem. In: VIRCHOW R. (Ed.) Gesammelte Abhandlungen zur wissenchaftlichen Medizin. Frankfurt: Von Meidinger Sohn, 1856. p. 458-636.

35 LIP, G. Y.; BEEVERS, D. G. Abnormalities of rheology and coagulation in hypertension. J. Hum. Hypertens., v. 8, p. 693-701, 1994.

36 LEE, A. J. The role of rheology and haemostatic factors in hypertension. J. Hum. Hypertens., v. 11, p.767-776, 1997.

37 BLANN, A.; TABERNER, D. A. Annotation: a reliable marker of endothelial cell dysfunction: does it exist? Br. J. Haematol., v. 90, p. 244-248, 1995.

38 LI-SAW-HEE, F. L.; BLANN, A. D.; LIP, G. Y. The detection of endothelial dysfunction in patients with essential hypertension. Int. J. Cardiol., v. 61, p. 171-174, 1997.

39 LOWE, G. D. O. Blood rheology in general medicine and surgery. Balliere's Clin. Haematol., v. 1, p. 827-861, 1987.

40 GLEN, S. K. et al. White-coat hypertension as a cause of cardiovascular dysfunction. Lancet v. 348, p. 654-657, 1996. 
41 SCHWARTZKOPFF, B.; MUNDHENKE, M.; STRAUER, B. E. Remodelling of intramyocardial arterioles and extracellular matrix in patients with arterial hypertension and impaired coronary reserve. Eur. Heart J., v. 16 (Suppl. I), p. 82-86, 1995.

42 LOWE, G. D. O. Haemostatic risk factors for arterial and venous thrombosis. In: POLLER, L. LUDLUM, C. A. Recent advances in blood coagulation. 7. ed. Edinburgh: Churchill Livingstone; 1997, p. 69-96.

43 SAWADA, K. et al. Hypertension associated with reduced plasma thrombomodulin levels and a hypercoagulable state in rats. Clin. Exp. Hypertens., v. 25, n. 2, p.73-84, 2003.

44 HUZOOR-AKBAR; KUNDU, N.; KORNHAUSER, R. Normal thrombin binding leads to greater fibrinogen binding and increased platelet aggregation in spontaneously hypertensive rats. Life Sci., v. 53, n. 26, p.1967-1974, 1993.

45 DE CLERCK, F. Blood platelets in human essential hypertension. Agents Actions., v.18, p. 563-580, 1986.

46 TEGER-NILSSON, A. C. et al. Fibrinogen and plasminogen activator inhibitor-1 levels in hypertension and coronary heart disease: potential effects of B-blockade. Circulation., v. 84, (Suppl. 6), p. 72-77, 1991.

47 VU, T. K. et al. Molecular cloning of a functional thrombin receptor reveals a novel proteolityc mechanism of receptor activation. Cell., v. 64. p. 1057-1068, 1991.

48 NYSTEDT, S. et al. Molecular cloning of a potential proteinase activated receptor. Proc. Natl. Acad. Sci. U.S.A., v. 91, p. 9208-9212, 1994.

49 FOX, M. T. et al. Identification of potential activators of proteinase-activated receptor-2. FEBS Lett., v. 417, p. 267-269, 1997.

50 MIRZA, H. et al. Mitogenic responses mediated through the proteinase activated receptor-2 are induced by expressed forms of mast cell alpha- or beta-tryptases. Blood., v. 90, p. 3914-3922, 1997.

51 ISHIHARA, H., et al. Protease-activated receptor 3 is a second thrombin receptor in humans. Nature., v. 386, p. 502-506, 1997.

52 KAHN, M. L. et al. A dual thrombin receptor system for platelet activation. Nature., v. 394, p. 690-694, 1998.

53 XU, W. F. et al. Cloning and characterization of human protease-activated receptor 4. Proc. Natl. Acad. Sci. U.S.A., v. 95, p. 6642-6646, 1998.

54 DERY, O. et al. Proteinase-activated receptors: novel mechanisms of signaling by serine proteases. Am. J. Physiol., v. 274, p. C1429- C1452, 1998.

55 MACFARLANE, S. R. et al. Proteinase-activated receptors. Pharmacol. Rev., v. 53, p. 245-282, 2001. 
56 ESMON, C. T. The protein C anticoagulant pathway. Arterioscler. Thromb., v. 12, p. 135-145, 1992.

57 ROYO, T. et al. Differential intracellular trafficking of von Willebrand factor (vWF) and $\mathrm{vWF}$ propeptide in porcine endothelial cells lacking Weibel-Palade bodies and in human endothelial cells. Atherosclerosis., v. 167, p. 55-63, 2003.

58 LEIRISALO-REPO, M. The present knowledge of the inflammatory process and the inflammatory mediators. Pharmacol. Toxicol., v. 75, (Suppl 2), p. 1-3, 1994.

59 BRASS, L. F. et al. Receptor and G protein-mediated responses to thrombin in HEL cells. J. Biol. Chem., v. 266, p. 958-965, 1991.

60 MITCHELL, C. A. et al. Thrombin-stimulated immunoprecipitation of phosphatidylinositol 3-kinase from human platelets. Proc. Natl. Acad. Sci. USA., v. 87, p. 9396-9400, 1990.

61 GUTKIND, J. S.; LACAL, P. M.; ROBBINS, K. C. Thrombin-dependent association of phosphadidylinositol-3 kinase with p60c-src and p59fyn in human platelets. Mol. Cell Biol., v. 10, p. 3806-3809, 1990.

62 BABICH, M.; KING, K. L.; NISSENSON, R. A. Thrombin stimulates inositol phosphate production and intracellular free calcium by a pertussis toxin-insensitive mechanism in osteosarcoma cells. Endocrinology., v. 126, p. 948-954, 1990.

63 GOSPODAROWICZ, D. et al. Control of proliferation of human vascular endothelial cells. Characterization of the response of human umbilical vein endothelial cells to fibroblast growth factor, epidermal growth factor, and thrombin. J. Cell Biol., v. 77, p. 774-788, 1978.

64 CHEN, L. B.; BUCHANAN, J. M. Mitogenic activity of blood components. I. Thrombin and prothrombin. Proc. Natl. Acad. Sci. USA v. 72, p. 131-135, 1975.

65 VU, T. K. et al. Domains specifying thrombin-receptor interaction. Nature., v. 353, p. 674-677, 1991.

66 BOUTON, M. C. et al. Thrombin interaction with a recombinant N-terminal extracellular domain of the thrombin receptor in an acellular system. Biochem. J., v. 305, p. 635-641, 1995.

67 SEILER, S. M. et al. Inhibition of thrombin and SFLLR-peptide stimulation of platelet aggregation, phospholipase $\mathrm{A} 2$ and $\mathrm{Na}^{+} / \mathrm{H}^{+}$exchange by a thrombin receptor antagonist. Biochem. Pharmacol., v. 49, p. 519-528, 1995.

68 KONG, W. et al. Luminal trypsin may regulate enterocytes through proteinaseactivated receptor 2. Proc. Natl. Acad. Sci. USA., v. 94, p. 8884-8889, 1997.

69 NGUYEN, T. D. et al. Trypsin activates pancreatic duct epithelial cell ion channels through proteinase-activated receptor-2. J. Clin. Invest., v. 103, p. 261-269, 1999. 
70 KOSHIKAWA, N. et al. Expression of trypsin in vascular endothelial cells. FEBS Lett., v. 409, p. 442-448, 1997.

71 KOSHIKAWA, N. et al. Expression of trypsin by epithelial cells of various tissues, leukocytes, and neurons in human and mouse. Am. J. Pathol., v. 153, p. 937- 944, 1998.

72 KOIVUNEN, E.; HUHTALA, M. L.; STENMAN U. H. Human ovarian tumorassociated trypsin. Its purification and characterization from mucinous cyst fluid and identification as an activator of pro-urokinase. J. Biol. Chem., v. 264, p. 14095-14099, 1989.

73 AKERS, I. A. et al. Mast cell tryptase stimulates human lung fibroblast proliferation via protease-activated receptor-2. Am. J. Physiol. Lung Cell. Mol. Physiol., v. 278, p. L193L201, 2000.

74 BERGER, P. et al. Selected contribution: tryptase-induced PAR-2-mediated $\mathrm{Ca}(2+)$ signaling in human airway smooth muscle cells. J. Appl. Physiol., v. 91, n. 2, p. 995-1003, 2001.

75 CORVERA, C. U. et al. Mast cell tryptase regulates rat colonic myocytes through proteinase-activated receptor 2. J. Clin. Invest., v. 100, p. 1383-1393, 1997.

76 CORVERA, C. U. et al. Thrombin and mast cell tryptase regulate guinea-pig myenteric neurons through proteinase-activated receptors-1 and -2. J. Physiol., v. 517, p. 741$756,1999$.

77 MOLINO, M. et al. Interactions of mast cell tryptase with thrombin receptors and PAR-2. J. Biol. Chem., v. 272, p. 4043-4049, 1997.

78 STEINHOFF, M. et al. Agonists of proteinase-activated receptor 2 induce inflammation by a neurogenic mechanism. Nat. Med., v. 6, p. 151-158, 2000.

79 SAMBRANO, G. R. et al. Cathepsin G activates protease-activated receptor-4 in human platelets. J. Biol. Chem., v. 275, p. 6819-6823, 2000.

80 UEHARA, A. et al. Activation of human oral epithelial cells by neutrophil proteinase 3 through protease-activated receptor-2. J. Immunol., v. 169, p. 4594-4603, 2002.

81 CAMERER, E.; HUANG, W.; COUGHLIN, S. R. Tissue factor- and factor Xdependent activation of protease-activated receptor 2 by factor VIIa. Proc. Natl. Acad. Sci. USA., v. 97, p. 5255-5260, 2000.

82 RIEWALD, M.; RUF, W. Mechanistic coupling of protease signaling and initiation of coagulation by tissue factor. Proc. Natl. Acad. Sci. USA., v. 98, p. 7742-7747, 2001.

83 RIEWALD, M. et al. Activation of endothelial cell protease activated receptor 1 by the protein C pathway. Science., v. 296, n. 5574, p. 1880-1882, 2002.

84 HIRANO, K. The roles of proteinase-activated receptors in vascular physiology and pathophysiology. Arterioscler. Tromb. Vasc. Biol., v. 27, p. 27-36, 2007. 
85 MOLINO, M. et al. Endothelial cell thrombin receptors and PAR-2 - two proteaseactivated receptors located in a single cellular environment. J. Biol. Chem., v. 272, p. 11133$11141,1997$.

86 LANGER, F. et al. Endothelial protease-activated receptor-2 induces Tissue Factor expression and von Willebrand factor release. Br. J. Haematol., v. 105, p. 542-550, 1999.

87 SCHMIDT, V. A. et al. The human poteinase-activated receptor-3 (PAR-3) gene identification within a PAR gene cluster and characterization in vascular endothelial cells and platelets. J. Biol. Chem., v. 273, p. 15061-15068, 1998.

88 CUPIT, L. D.; SCHMIDT, V. A.; BAHOU, W. F. Proteolytically Activated Receptor3 - A Member of an Emerging Gene Family of Protease Receptors Expressed on Vascular Endothelial Cells and Platelets. Trends Cardiovasc. Med., v. 9, n. 1-2, p. 42-48, 1999.

89 HAMILTON, J. R.; FRAUMAN, A. G.; COCKS, T. M. Increased expression of protease-activated receptor-2 (PAR2) and PAR4 in human coronary artery by inflammatory stimuli unveils endothelium-dependent relaxations to PAR2 and PAR4 agonists. Circ. Res., v. 89, p. 92, 2001.

90 BRETSCHNEIDER, E. et al. Evidence for functionally active protease-activated receptor-4 (PAR-4) in human vascular smooth muscle cells. Br. J. Pharmacol., v. 132, n. 7, p. 1441-1446, 2001.

91 ELLIS, C. A. et al. Thrombin induces proteinase-activated receptor-1 gene expression in endothelial cells via activation of Gi-linked Ras/mitogen-activated protein kinase pathway. J. Biol. Chem., v. 274, p. 13718-13727, 1999.

92 SHINOHARA, T. et al. Regulation of proteinase-activated receptor 1 by inflammatory mediators in human vascular endothelial cells. Cytokine., v. 19, p. 66-75, 2002.

93 YAN, W. et al. Tumor necrosis factor decreases thrombin receptor expression in endothelial cells. J. Cell. Physiol., v. 166, p. 561-567, 1996.

94 NYSTEDT, S.; RAMAKRISHNAN, V.; SUNDELIN, J. The proteinase-activated receptor 2 is induced by inflammatory mediators in human endothelial cells. Comparison with the thrombin receptor. J. Biol. Chem., v. 271, p. 14910-14915, 1996.

95 SCHINI-KERTH, V. B. et al. Aggregating human platelets stimulate the expression of thrombin receptors in cultured vascular smooth muscle cells via the release of transforming growth factor-1 and platelet-derived growth factor AB. Circulation., v. 96, p. 3888-3896, 1997.

96 CICALA, C. et al. Protease-activated receptor-2 involvement in hypotension in normal and endotoxemic rats in vivo. Circulation., v. 99, p. 2590-2597, 1999.

97 HERKERT, O. et al. Sex steroids used in hormonal treatment increase vascular procoagulant activity by inducing thrombin receptor (PAR-1) expression: role of the glucocorticoid receptor. Circulation., v. 104, p. 2826-2831, 2001. 
98 WILCOX, J. et al. Characterization of thrombin receptor expression during vascular lesion formation. Circ. Res., v. 75, p. 1029-1038, 1994.

99 DAMIANO, B. P. et al. Increased expression of protease activated receptor-2 (PAR-2) in balloon-injured rat carotid artery. Thromb. Haemost., v. 81, p. 808-814, 1999.

100 NGUYEN, K. T. et al. Shear stress reduces protease activated receptor-1 expression in human endothelial cells. Ann. Biomed. Engineering., v. 29, p. 145-152, 2001.

101 PAPADAKI, M. et al. Differential regulation of protease activated receptor-1 and tissue plasminogen activator expression by shear stress in vascular smooth muscle cells. Circ. Res., v. 83, p. 1027-1034, 1998.

102 NGUYEN, K. T. et al. Cyclic strain increases protease-activated receptor-1 expression in vascular smooth muscle cells. Hypertension., v. 38, p. 1038-1043, 2001.

103 WANG, J. et al. Deficiency of microvascular thrombomodulin and upregulation of protease-activated receptor-1 in irradiated rat intestine: possible link between endothelial dysfunction and chronic radiation fibrosis. Am. J. Pathol., v. 160, p. 2063-2072, 2002.

104 KU, D. D.; DAI, J. Expression of thrombin receptors in human atherosclerotic coronary arteries leads to an exaggerated vasoconstrictory response in vitro. J. Cardiovasc. Pharmacol., v. 30, p. 649-657, 1997.

105 NELKEN, N. A. et al. Thrombin receptor expression in normal and atherosclerotic human arteries. J. Clin. Invest., v. 90, p. 1614-1621, 1992.

106 QUINN CAPERS, I., V. et al. Vascular thrombin receptor regulation in hypertensive rats. Circ Res., v. 80, n. 6, p. 838-844, 1997.

107 WANG, Y.; GU, Y.; LUCAS, M. J. Expression of thrombin receptors in endothelial cells and neutrophils from normal and preeclamptic pregnancies. J. Clin. Endocrinol. Metab., v. 87, n. 8, p. 3728-3734, 2002.

108 GRANDALIANO, G. et al. Protease-activated receptor 1 and plasminogen activator inhibitor 1 expression in chronic allograft nephropathy: the role of coagulation and fibrinolysis in renal graft fibrosis. Transplantation., v. 72, p. 1437-1443, 2001.

109 COUGHLIN, S. R. Thrombin signaling and protease activated receptors. Nature., v. 407, p. 258-264, 2000.

110 BAFFY, G. et al. G protein coupling to the thrombin receptor in Chinese hamster lung fibroblasts. J. Biol. Chem., v. 269, p. 8483-8487, 1994.

111 BENKA, M. L. et al. The thrombin receptor in human platelets is coupled to a GTP binding protein of the Gaq family. FEBS Lett., v. 363, p. 49-52, 1995.

112 OGINO, Y.; TANAKA, K.; SHIMIZU, N. Direct evidence for two distinct G proteins coupling with thrombin receptors in human neuroblastoma SH-EP cells. Eur. J. Pharmacol., v. 316, p. 105-109, 1996. 
113 HUNG, D. T. et al. The cloned platelet thrombin receptor couples to at least two distinct effectors to stimulate phosphoinositide hydrolysis and inhibit adenylyl cyclase. J. Biol. Chem., v. 267, p. 20831-20834, 1992.

114 KANTHOU, C. et al. Involvement of pertussis toxin-sensitive and insensitive G proteins in a-thrombin signaling on cultured human vascular smooth muscle cells. Cell. Signal., v. 8, p. 59-66, 1996.

115 OFFERMANNS, S. et al. G proteins of the G12 family are activated via thromboxane A2 and thrombin receptors in human platelets. Proc. Natl. Acad. Sci. USA., v. 91, p. 504508, 1994.

116 TAYLOR, S. J. et al. Activation of the b1 isozyme of phospholipase C by alpha subunits of the Gq class of G proteins. Nature., v. 350, p. 516-518, 1991.

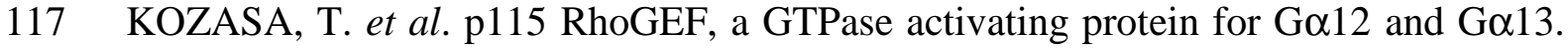
Science., v. 280, p. 2109-2111, 1998.

118 HART, M. J. et al. Direct stimulation of the guanine nucleotide exchange activity of

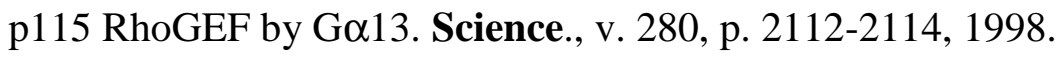

119 GOHLA, A. et al. Differential involvement of $\mathrm{G} \alpha 12$ and $\mathrm{G} \alpha 13$ in receptor-mediated stress fiber formation. J. Biol. Chem., v. 274, p. 17901-17907, 1999.

120 CHIKUMI, H.; FUKUHARA, S.; GUTKIND, J. S. Regulation of G protein-linked guanine nucleotide exchange factors for Rho, PDZ-RhoGEF, and LARG by tyrosine phosphorylation: evidence of a role for focal adhesion kinase. J. Biol. Chem., v. 277, p. 12463-12473, 2002.

121 FUKUHARA, S. et al. Signaling from G protein-coupled receptors to ERK5/Big MAPK 1 involves $\mathrm{G} \alpha \mathrm{q}$ and $\mathrm{G} \alpha 12 / 13$ families of heterotrimeric $\mathrm{G}$ proteins. Evidence for the existence of a novel Ras and Rho-independent pathway. J. Biol. Chem., v. 275, p. 2173021736, 2000.

122 MAJUMDAR, M. et al. A rho exchange factor mediates thrombin and Go12-induced cytoskeletal responses. J. Biol. Chem., v. 274, p. 26815-26821, 1999.

123 NGUYEN, Q. D. et al. RhoA and RhoD-dependent regulatory switch of G $\alpha$ subunit signaling by PAR-1 receptors in cellular invasion. FASEB J., v. 16, p. 565-576, 2002.

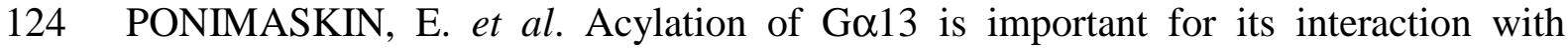
thrombin receptor, transforming activity and actin stress fiber formation. FEBS Lett., v. 478, p. 173-177, 2000.

125 KLAGES, B. et al. Activation of Go12/13 results in shape change and Rho/Rhokinase-mediated myosin light chain phosphorylation in mouse platelets. J. Cell Biol., v. 144, p. 745-754, 1999. 
126 WOJCIAK-STOTHARD, B. et al. Rho and Rac but not Cdc42 regulate endothelial cell permeability. J. Cell Sci., v. 114 (Pt 7), p. 1343-1355, 2001.

127 VOURET-CRAVIARI et al. Regulation of the actin cytoskeleton by thrombin in human endothelial cells: role of Rho proteins in endothelial barrier function. Mol. Biol. Cell., v. 9, p. 2639-2653, 1998.

128 VAN NIEUW AMERONGEN, G. P. et al. Activation of RhoA by thrombin in endothelial hyperpermeability: role of Rho kinase and protein tyrosine kinases. Circ. Res., v. 87, p. 335-340, 2000.

129 VAN NIEUW AMERONGEN, G. P.; VERMER, M. A.; VAN HINSBERGH, V. W. Role of RhoA and Rho kinase in lisophosphatidic acid-induced endothelial barrier dysfunction. Arterioscler. Thromb. Vasc. Biol., v. 20, p. E127-E133, 2000.

130 CARBAJAL, J. M. et al. ROCK mediates thrombin's endothelial barrier dysfunction. Am. Physiol., v. 279, p. C195-C204, 2000.

131 BAUER, M. et al. Dichotomous regulation of myosin phosphorylation and shape change by Rho-kinase and calcium in intact human platelets. Blood., v. 94, p. 1665-1672, 1999.

132 BODIE, S. L. et al. Thrombin-induced activation of RhoA in platelet shape change. Biochem. Biophys. Res. Commun., v. 287, p. 71-76, 2001.

133 NISHIOKA, H. et al. Small GTPase Rho regulates thrombin-induced platelets aggregation. Biochem. Res. Commun., v. 280, p. 970-975, 2001.

134 SEASHOLTZ, T. M. et al. Rho and Rho kinase mediate thrombin-stimulated vascular smooth muscle cells DNA synthesis and migration. Circ. Res., v. 84, p. 1186-1193, 1999.

135 SHIMIZU, H. et al. Characterization of the myosin-binding subunit of smooth muscle myosin phosphatase. J. Biol. Chem., v. 269, p. 30407-30411, 1994.

136 KIMURA, K. et al. Regulation of myosin phosphatase by Rho and Rho-associated kinase (Rho-kinase). Science., v. 273, p. 245-248, 1996.

137 AMANO, M. et al. Phosphorylation and activation of myosin by Rho-associated kinase (Rho-kinase). J. Biol. Chem., v. 271, p. 20246-20249, 1996.

138 ESSLER, M. et al. Thrombin inactivates myosin light chain phosphatase via Rho and its target Rho kinase in human endothelial cells. J. Biol. Chem., v. 273, p. 21867-21874, 1998.

139 Clapham, D. E.; NEER, E. J. G protein $\beta \gamma$ subunits. Annu. Rev. Pharmacol. Toxicol., v. 37, p. 167-203, 1997.

140 CHEN,Y. H. et al. Activation of Src family kinase activity by the G protein-coupled thrombin receptor in growth-responsive fibroblasts. J. Biol. Chem., v. 269, p. 27372-27377, 1994. 
141 COLLINS, L. R. et al. The G12 coupled thrombin receptor stimulates mitogenesis through the Shc SH2 domain. Oncogene., v. 15, p. 595-600, 1997.

142 RICKETTS, W. A.; BROWN, J. H.; OLEFSKY, J. M. Pertussis toxin-sensitive and insensitive thrombin stimulation of Shc phosphorilation and mitogenesis are mediated through distinct pathways. Mol. Endocrinol., v. 13, p. 1988-2001, 1999.

143 CHEN, Y. et al. Shc adaptor proteins are key transducers of mitogenic signaling mediated by the G protein-copupled thrombin receptor. EMBO J., v. 15, p. 1037-1044, 1996.

144 KAHAN, C. et al. Coordinate, biphasic activation of p44 mitogen-activated protein kinase and S6 kinase by growth factors in hamster fibroblasts. Evidence for thrombin-induced signals different form phosphoinositide turnover and adenylylcyclase inhibition. J. Biol. Chem., v. 267, p. 13369-13375, 1992.

145 MORRIS, A. J. et al. Regulation of phophoinositide-3-kinase by G protein $\beta$ subunits in a rat osteosarcoma cell line. Mol. Pharmacol., v. 48, p. 532-539, 1995.

146 ZHANG, J. et al. Activated phosphoinositide 3-kinase associates with mmbrane skeleton in thrombin-exposed platelets. J. Biol. Chem., v. 267, p. 4686-4692, 1992.

147 WALKER, T. R. et al. Platelet-derived growth factor-BB and thrombin activate phosphoinositide 3-kinase and protein kinase B: role in mediating airway smooth muscle proliferation. Mol. Pharmacol., v. 54, p. 1007-1015, 1998.

148 BOS, J. L. et al. A target for phosphoinositide 3-kinase: Akt/PKB. Trends Biochem. Sci., v. 20, p. 441-442, 1995.

149 BURGERING, B. M.; COFFER, P.J. Protein kinase B (c-Akt) in phosphatidylinositol3-OH kinase signal transduction. Nature., v. 376, p. 599-602, 1995.

150 FRANKE, T. F. et al. The protein kinase encoded by the Akt proto-oncogene is a target of the PDGF-activated phosphatidylinositol 3-kinase. Cell., v. 81, p. 727-736, 1995.

151 CHUNG, J. et al. PDGF and insulin-dependent $\mathrm{pp} 70^{\mathrm{s} 6 \mathrm{k}}$ activation mediated by phosphatidylinositol-3-OH kinase. Nature., v. 370, p. 71-75, 1994.

152 BELHAM, C. M. et al. Evidence that thrombin-stimulated DNA synthesis in pulmonary arterial fibrlblasts involves phosphatidylinositol 3-kinase-dependent p70 ribosomal S6 kinase activation. Cell Signalling., v. 9, n.1 p. 109 - 116, 1997.

153 CHEATHAM, B. et al. Phosphatidylinositol 3-kinase activation is required for insulin stimulation of pp70 S6 kinase, DNA synthesis, and glucose transporter translocation.

Mol. Cell. Biol., v. 14, p. 4902-4911, 1994.

154 DAUB, H. et al. Role of transactivation of the EGF receptor in signalling by Gprotein-coupled receptors. Nature., v. 379, p. 557-560, 1996.

155 COCKS, T. M.; MOFFATT, J. D. Protease-activated receptors: sentries for inflammation? Trends Pharmacol. Sci., v. 21, p. 103-108, 2000. 
156 KAWABATA, A. PAR-2: structure, fuction and relevance to human diseases of the gastric mucosa. Exp. Rev. Mol. Med., v. 16, p. 1-17, 2002.

157 NAKAYAMA et al. Mechanism of trypsin-induced endothelium-dependent vasorelaxation in the porcine coronary artery. Br. J. Pharmacol., v. 134, p. 815-826, 2001.

158 TEMKIN, V. et al. Tryptase activates the mitogen-activated protein kinase/activator protein-1 phathway in human peripheral blood eosinophils, causing cytokine production and release. J. Immunol., v. 169, p. 2662-2669, 2002.

159 CAMERER, E. et al. Genetic evidence that protease-activated receptors mediate factor Xa signaling in endothelial cells. J. Biol. Chem., v. 277, p. 16081-16087, 2002.

160 BELHAM, C. M. et al. Trypsin stimulates proteinase-activated receptor-2-dependent and independent activation of mitogen-activated protein kinases. Biochem. J., v. 320, p. 939946, 1996.

161 YU, Z. et al. Protein-tyrosine phosphatase SHP2 is positively linked to proteinaseactivated receptor 2-mediated mitogenic pathway. J. Biol. Chem., v. 272, p. 7519-7524, 1997.

162 KAWABATA, A. et al. Activation of protease-activated receptor 2 (PAR-2) triggers mucin secretion in the rat sublingual gland. Biochem. Biophys. Res. Commun., v. 270, p. 298-302, 2000.

163 MIZUNO, O. Mechanism of endothelium-dependent relaxation induced by thrombin in the pig coronary artery. Eur. J. Pharmacol., v. 351, p. 67-77, 1998.

164 OSSOVSKAYA, V. S.; BUNNETT, N. W. Protease-activated receptors: contribution to physiology and disease. Physiol. Rev., v. 84, p. 579 - 621, 2004.

165 MOLINO, M. et al. Proteolysis of the human platelet and endothelial cell thrombin receptor by neutrophil-derived cathepsin G. J. Biol. Chem., v. 270, p. 11168-11175, 1995.

166 RENESTO, P. et al. Specific inhibition of thrombin induced cell activation by the neutrophil proteinases elastase, cathepsin $\mathrm{G}$, and proteinase 3: evidence for distinct cleavage sites within the aminoterminal domain of the thrombin receptor. Blood., v. 89, p. 1944-1953, 1997.

167 SCHECHTER, N. M. et al. Reaction of mast cell proteases tryptase and chymase with protease activated receptors (PARs) on keratinocytes and fibroblasts. J. Cell. Physiol., v. 176, p. 365-373, 1998.

168 DULON, S. et al. Proteinase-activated receptor-2 and human lung epithelial cells: disarming by neutrophil serine proteinases. Am. J. Respir. Cell. Mol. Biol., v. 28, p. 339346, 2003.

169 UEHARA, A. et al. Neutrophil serine proteinases activate human nonepithelial cells to produce inflammatory cytokines through protease-activated receptor 2 . J. Immunol., v. 170, p. 5690-5696, 2003. 
170 CUMASHI, A. et al. Neutrophil proteases can inactivate human PAR3 and abolish the co-receptor function of PAR3 on murine platelets. Thromb. Haemostasis., v. 85, p. 533$538,2001$.

171 NAKAYAMA, T. et al. Unproductive cleavage and the inactivation of proteaseactivated receptor-1 by trypsin in vascular endothelial cells. Br. J. Pharmacol. v. 138, p. 121-130, 2003.

172 KRUPNICK, J. G.; BENOVIC, J. L. The role of receptor kinases and arrestins in G protein-coupled receptor regulation. Annu. Rev. Pharmacol. Toxicol., v. 38, p. 289-319, 1998.

173 ISHII, K. et al. Inhibition of thrombin-receptor signaling by a G-protein coupled receptor kinase. Functional specificity among G-protein cloupled receptor kinases. J. Biol. Chem., v. 269, p. 1125-1130, 1994.

174 INGLESE, J. et al. Structure and mechanism of the G protein-coupled receptor kinases. J. Biol. Chem., v. 268, p. 23735-23738, 1993.

175 TIRUPPATHI, et al. G protein-coupled receptor kinase-5 regulates thrombin-activated signaling in endothelial cells. Proc. Natl. Acad. Sci. USA., v. 97, p. 7440-7445, 2000.

176 SCHMID, S. L.; MCNIVEN, M. A.; DE CAMILLI, P. Dynamin and its partners: a progress report. Curr. Opin. Cell. Biol., v. 10, p. 504-512, 1998.

177 TSAO, P.; CAO, T. T.; VON ZASTROW, M. Role of endocytosis in mediating downregulation of G-protein coupled receptors. Trends Pharmacol. Sci., v. 22, p. 91-96, 2001 .

178 FERGUSON, S. S. G. Evolving concepts in G protein-coupled receptor endocytosis: the role in receptor desensitization and signaling. Pharmacol. Rev., v. 53, p.1-24, 2001.

179 PALS-RYLAARSDAM, R. et al. Internalization of the $\mathrm{m} 2$ muscarinic acetylcholine receptor. J. Biol. Chem., v. 272, p. 23682-23689, 1997.

180 VICKERY, R. G.; VON ZASTROW, M. Distinct dynamin-dependent and independent mechanisms target structurally homologous dopamine receptors to different endocytic membranes. J. Cell. Biol., v. 144, p. 31-43, 1999.

181 KU, D. D.; ZALESKI, J. K. Receptor mechanism of thrombin-induced endotheliumdependent and endothelium-independent coronary vascular effects in dogs. J. Cardiovasc. Pharmacol., v. 22, n. 4, p. 609-616, 1993.

182 TESFAMARIAM, B. Distinct Receptors and Signaling Pathways in $\alpha$-Thrombin - and Thrombin Receptor Peptide-Induced Vascular Contractions. Cir. Res., v. 74, p. 930-936, 1994.

183 DAMIANO, B. P. Cardiovascular actions of thrombin receptor activation in vivo. J. Pharmacol. Exp. Ther., v. 279, p. 1365-1378, 1996. 
184 STEINBERG, S. F. et al. Thrombin modulates phosphoinositide metabolism, cytosolic calcium, and impulse initiation in the heart. Circ. Res., v. 68, p. 1216-1229, 1991.

185 MIZUNO O, et al. Proteolysis and phosphorylation-mediated regulation of thrombin receptor activity in in situ endothelial cells. Eur. J. Pharmacol., v. 389, p. 13-23, 2000.

186 HAMILTON, J. R.; COCKS, T. M. Heterogeneous mechanisms of endotheliumdependent relaxation form thrombin and peptide activators of protease-activated receptor- 1 in porcine isolated coronary artery. Br. J. Pharmacol., v. 130, p. 181-188, 2000.

187 MURAMATSU, I. et al. Vascular actions of thrombin receptor peptide. Can. J. Physiol. Pharmacol., v. 70, p. 996-1003, 1992.

188 TESFAMARIAM, B. Thrombin receptor-mediated vascular relaxation differentiated by a receptor antagonist and desensitization. Am. J. Physiol-Heart Circ. Physiol., v. 36 p. H1962-H1967, 1994.

189 ZALESKI, J. K. KU, D. D. Receptor mechanism of thrombin-induced endotheliumdependent and endothelium-independent coronary vascular effects in dogs. FASEB J., v. 7, p. A118, 1993.

190 DEBLOIS, D. et al. Synergism between the contractile effect of epidermal growth factor and that of Des-Arg9-bradykinin or of alpha-thrombin in rabbit aortic rings. Br. J. Pharmacol., v. 105, p. 959-967, 1992.

191 ANTONACCIO, M. J. et al. Effects of thrombin and thrombin receptor activating peptides on rat aortic vascular smooth-muscle. J. Pharmacol. Exp. Ther., v. 266, p. 125-132, 1993.

192 ANTONACCIO, M. J.; NORMANDIN, D. Role of Ca21 in the vascular contraction caused by a thrombin receptor activating peptide. Eur. J. Pharmacol., v. 256, p. 37-44, 1994.

193 GODIN, D. et al. Mode of action of thrombin in the rabbit aorta. Br. J. Pharmacol., v. 115, p. 903-908, 1995.

194 DERKACH, D. N. et al. Thrombin causes endothelium-dependent biphasic regulation of vascular tone in the porcine renal interlobar artery. Br. J. Pharmacol., v. 131, p. 16351642, 2000.

195 TOGNETTO, M. et al. Proteinase-activated receptor (PAR-1) activation contracts the isolated human renal artery in vitro. Br. J. Pharmacol., v. 139, p. 21-27, 2003.

196 TAY-UYBOCO, J. et al. Contractile actions of thrombin receptor-derived polypeptides in human umbilical and placental vasculature: evidence for distinct receptor systems. Br. J. Pharmacol., v. 115, p. 569-578, 1995.

197 PINHEIRO, J. M. B.; ANDERSEN, T. T.; MALIK, A. B. Receptor mechanism of thrombin mediated pulmonary vasodilation in neonates. Am. J. Physiol., v. 265, p. L355L359, 1993. 
198 LUM, H. et al. Thrombin receptor activation peptide induces pulmonary vasoconstriction. Am. J. Physiol., v. 266, p. C448-C454, 1994.

199 SOIFER, S. et al. Disparate temporal expression of the prothrombin and thrombin receptor genes during mouse development. Am. J. Pathol., v. 144, p. 60-69, 1994.

200 AL-ANI, B.; SAIFEDDINE, M.; HOLLENBERG, M. D. Detection of functional receptors for the proteinase-activated-receptor-2-activating polypeptide, SLIGRL-NH2, in rat vascular and gastric smooth muscle. Can. J. Physiol. Pharmacol., v. 73, p. 1203-1207, 1995.

201 ROY, S. S. et al. Dual endothelium-dependent vascular activities of proteinaseactivated receptor-2-activating peptides: evidence for receptor heterogeneity. Br. J. Pharmacol., v. 123, p. 1434-1440, 1998.

202 HWA, J. J. et al. Evidence for the presence of a proteinase-activated receptor distinct from the thrombin receptor in vascular endothelial cells. Circ. Res., v. 78, p. 581-588, 1996.

203 HAMilton, J. R.; NGUYEN, P. B.; COCKS, T. M. Atypical Protease-Activated Receptor Mediates Endothelium-Dependent Relaxation of Human Coronary Arteries. Circ. Res., v. 82, p. 1306-1311, 1998.

204 SOBEY C. G.; COCKS, T. M. Activation of protease-activated receptor-2 (PAR-2) elicits nitric oxide-dependent dilatation of the basilar artery in vivo. Stroke., v. 29, p. 14391444, 1998.

205 SOBEY, C. G.; MOFFATT, J. D.; COCKS, T. M. Evidence for selective effects of chronic hypertension on cerebral artery vasodilatation to protease-activated receptor-2 activation. Stroke., v. 30, p. 1933-1941, 1999.

206 KOMURO T, et al. The involvement of a novel mechanism distinct from the thrombin receptor in the vasocontraction induced by trypsin. Br. J. Pharmacol., v. 120, p. 851-856, 1997.

207 MAGAZINE, H. I.; KING, J. M.; SRIVASTAVA, K. D. Protease activated receptors modulate aortic vascular tone. Int. J. Cardiol., v. 53, p. S75-S80, 1996.

208 TROTTIER, G. et al. PAR-2 elicits afferent arteriolar vasodilation by NO-dependent and NO-independent actions. Am. J. Phisiol. Renal Phisiol., v. 282, p. F891-F897, 2001.

209 MCGUIRE, J. J. et al. Multiple mechanisms of vascular smooth muscle relaxation by the activation of proteinase-activated receptor 2 in mouse mesenteric arterioles. Br. $\mathbf{J}$. Pharmacol., v. 135, p. 155-169, 2002.

210 ROBIN, J. et al. Protease-Activated Receptor 2-Mediated Vasodilatation in Humans In Vivo - Role of Nitric Oxide and Prostanoids. Circulation., v. 107, p. 954-959, 2003.

211 HAMILTON, J. R. et al. Enzymatic activation of endothelial protease-activated receptors is dependent on artery diameter in human and porcine isolated coronary arteries. Br. J. Pharmacol., v. 136, p. 492-501, 2002. 
212 GARLAND, C.; BEVAN, J. A. Alpha adrenoceptor antagonists selectively reduce thrombin-stimulated contraction in rabbit arteries. J. Pharmacol. Exp. Ther., v. 238, p. 947953, 1986.

213 HAVER, V. M.; NAMM, D. H. Generation of a vasoactive substance in human plasma during coagulation: evidence of thrombin-induced contraction of rabbit aorta and dog coronary artery. Blood Vessels., v. 20, p. 92-98, 1983.

214 WHITE, R. P. et al. Cerebral arterial contractions induced by human and bovine thrombin. Stroke., v. 11, p. 363-368, 1980.

215 DE MEY, J. G.; VANHOUTTE, P. M. Endothelium-dependent inhibitory effects of acetylcholine, adenosine, thrombin and arachidonic acid in the canine femoral artery. $\mathbf{J}$. Pharmacol. Exp. Ther., v. 222, p. 166-173, 1982.

216 GEBREMEDHIN, D. et al. Species specificity of thrombin-induced changes in vascular tone. Eur. J. Pharmacol., v. 132, p. 71-74, 1986.

217 TESFAMARIAM, B. et al. Involvement of the "tethered ligand" receptor in thrombininduced endothelium-dependent relaxations. Am. J. Physiol., v. 265; p. H1744H1749, 1993.

218 RAPOPORT, R. M.; DRAZNIN, M. B.; MURAD, F. Mechanisms of adenosine triphosphate, thrombin, and trypsin-induced relaxation of rat thoracic aorta. Circ. Res., v. 55; p. $468-479,1984$.

219 SAIFEDDINE, M. et al. Endothelium dependent contractile actions of proteinaseactivated receptor-2-activating peptides in human umbilical vein: release of a contracting factor via a novel receptor. Br. J. Pharmacol., v. 125, p. 1445-1454, 1998.

220 MARTINEZ, L. L. Influência do bloqueador de canal de cálcio (Verapamil) e do antiinflamatório não-esteroidal (Diclofenaco de potássio) sobre o comportamento de leucócitos in vivo. $78 \mathrm{f}$. Tese (Doutorado em Ciências - Área: Farmacologia) - Instituto de Ciências Biomédicas, Universidade de São Paulo, São Paulo, 1999.

221 STEINBERG, S. F. The cardiovascular actions of protease-activated receptors. Mol. Pharmacol., v. 67, p. 2-11, 2005.

222 HIRANO, K.; KANAIDE, H. Role of protease-activated receptors in the vascular system. J. Atheroscl. Thromb., v. 10, n. 4, p. 211-225, 2003.

223 HOLlENBERG, M. D.; COMPTON, S. J. International Union of Pharmacology. XXVIII. Proteinase-activated receptors. Pharmacol. Rev., v. 54, p. 203-217, 2002.

224 MAJOR, C. D. et al. Extracellular mediators in atherosclerosis and thrombosis: lessons from thrombin receptor knockout mice. Arterioscler. Thromb. Vasc. Biol., v. 23, p. 931-939, 2003.

225 MOSER, M.; PATTERSON, C. Thrombin and vascular development: a sticky subject. Arterioscler. Thromb. Vasc. Biol., v. 23; p. 922-930, 2003. 
226 PATTERSON, C. et al. New tricks for old dogs: nonthrombotic effects of thrombin in vessel wall biology. Circ. Res., v. 88, p. 987-997, 2001.

227 Nakanishi-Matsui M, et al. PAR3 is a cofactor for PAR4 activation by thrombin. Nature., v. 404, p. 609-613, 2000.

228 MOMOTA, F. et al. Involvement of Gi/o in the PAR-4-induced NO production in endothelial cells. Biochem. Biophys. Res. Commun., v. 342, p. 365-371, 2006.

229 HOLLENBERG, M. D. et al. Proteinase-activated receptor 4 (PAR4): action of PAR4-activating peptides in vascular and gastric tissue and lack of cross-reactivity with PAR1 and PAR2. Can. J. Physiol. Pharmacol., v. 77, p. 458-464, 1999.

230 KATAOKA, H. et al. Protease-activated receptors 1 and 4 mediate thrombin signaling in endothelial cells. Blood., v.102, p. 3224-3231, 2003.

231 HOLLENBERG, M. D. et al. Proteinase-activated receptor-4: evaluation of tethered ligand-derived peptides as probes for receptor function and as inflammatory agonists in vivo. Br. J. Pharmacol., v. 143, p. 443-454, 2004.

232 MINAMI, T. et al. Thrombin and phenotypic modulation of the endothelium. Arterioscler. Thromb. Vasc. Biol., v. 24, p. 41-53, 2004.

233 MCLAUGHLIN, J. N. et al. Thrombin modulates the expression of a set of genes including thrombospondin-1 in human microvascular endothelial cells. J. Biol. Chem., v. 280, p. 22172-22180, 2005.

234 CAMERER, E. et al. Roles of protease-activated receptors in a mouse model of endotoxemia. Blood., v. 107, p. 3912-3921, 2006.

235 VERGNOLlE, N.; WALLACE, J. L.; HOLLENBERG, M. D. Activation of proteinase activated receptor-2 (PAR-2) induces leukocyte adhesion. FASEB J., v. 13, p. A668, 1999.

236 VERGNOLLE, N. Proteinase-activated receptor-2-activating peptides induce leukocyte rolling, adhesion, and extravasation in vivo. J. Immunol., v. 163, p. 5064-5069, 1999.

237 MIRZA, H.; YATSULA, V.; BAHOU, W. F. The proteinase activated receptor-2 (PAR-2) mediates mitogenic responses in human vascular endothelial cells - molecular characterization and evidence for functional coupling to the thrombin receptor. J. Clin. Invest., v. 97, p. 1705-1714, 1996.

238 STORCK, J. et al. Trypsin induced von Willebrand factor release from human endothelial cells is mediated by PAR-2 activation. Thromb. Res., v. 84, p. 463-473, 1996.

239 ZWEIFACH, B. W. Indirect methods for regional blood flow. Microscopic observation of circulation in rat mesoappendix and dog omentum, Use in study of vasotropic substances. Meth. Med. Rev., v. 1, p. 131-138, 1948. 
240 FORTES, Z. B.; LEME, J. B.; SCIVOLETTO, R. Influence of diabetes on the reactivity of mesentery microvessels to histamine, bradykinin and acetylcholine. Br. J. Pharmacol., v. 79, p. 143-147, 1983.

241 GOREN, R. W.; BOHLEN, H. G. Microvascular pressures in rat intestinal muscle and mucosal willi. Am. J. Physiol., v. 233, p. H685-H693, 1977.

242 TSUBOI H, et al. Role of the thrombin/protease-activated receptor 1 pathway in intestinal ischemia-reperfusion injury in rats. Am. J. Physiol. Gastrointest. Liver Physiol., v. 292, n. 2, p. G678-683, 2007.

243 CHIEN, E. K. et al. Protease-activated receptor isoform expression in pregnant and nonpregnant rat myometrial tissue. J. Soc. Gynecol. Investig., v. 10, n. 8, p. 460-468, 2003.

244 http://www.ncbi.nlm.nih.gov/blast

245 http://www.ncbi.nlm.nih.gov/sites/entrez

246 http://frodo.wi.mit.edu/cgi-bin/primer3/primer3_www.cgi

247 DUSSAULT, A.; POULIOT, M. Rapid and simple comparision of messenger RNA levels using real-time PCR. Biol. Proced. Online., v. 8, n. 1, p. 1-10, 2006.

248 TESFAMARIAM, B.; OGLETREE, M. L. Dissociation of endothelial cell dysfunction and blood pressure in SHR. Am. J. Physiol., v. 269, p. H189-H194, 1995.

249 CICALA, C. et al. Pharmacological dissection of vascular effects caused by activation of protease-activated receptors 1 and 2 in anesthetized rats. FASEB J., v. 15, n. 8, p. 14331435, 2001.

250 EMILSSON, K. et al. Vascular effects of proteinase-activated receptor 2 agonist peptide. J. Vasc. Res., v. 34, p. 267-272, 1997.

251 CHEUNG WM, et al. Receptor activating peptides distinguish thrombin receptor (PAR-1) and protease activated receptor 2 (PAR-2) mediated hemodynamic responses in vivo. Can. J. Physiol. Pharmacol., v. 76, p. 16-25, 1998.

252 McGUIRE, J. J. et al. Blood pressures, heart rate and locomotor activity during salt loading and angiotensin II infusion in protease-activated receptor 2 (PAR2) knockout mice. Physiology., v. 8, n. 20, 2008.

253 DAMIANO, B. P. et al. Cardiovascular responses mediated by protease-activated receptor-2 (PAR-2) and thrombin receptor (PAR-1) are distinguished in mice deficient in PAR-2 or PAR-1. J. Pharmacol. Exp. Ther., v. 288, p. 671-678, 1999.

254 NAPOLI, C. et al. Protase-activated receptor-2 modulates myocardial ischemiareperfusion injury in the rat heart. Proc. Natl. Acad. Sci. USA., v. 97, n. 7, p. 3678-3683, 2000 . 
255 DARROW, A. L. et al. Biological consequences of thrombin receptor deficiency in mice. Thromb. Haemost., v. 76, p. 860-866, 1996.

256 NILSSON, H.; AALKJÆR, C. Vasomotion: Mechanisms and Physiological Importance. Mol. Intervent., v. 3, p. 79-89, 2003.

257 STANSBERRY, K. B. et al. Impaired peripheral vasomotion in diabetes. Diabetes Care., v. 19, p. 715-721, 1996.

258 BENBOW, S. J. et al. Flow motion in peripheral diabetic neuropathy. Clin. Sci., v. 88, p. 191-196, 1995.

259 BOUSKELA, E. Effects of metformin on the wing microcirculation of normal and diabetic bats. Diabetes Metab., v.14, p. 560-565, 1988.

260 BOUSKELA, E.; CYRINO, F. Z.; WIERNSPERGER, N. Effects of insulin and the combination of insulin plus metformin (glucophage) on microvascular reactivity in control and diabetic hamsters. Angiology., v. 48, p. 503-514, 1997.

261 RENAUDIN, C. et al. Impaired microvascular responses to acute hyperglycemia in type I diabetic rats. J. Diabetes Complications., v. 13, p. 39-44, 1999.

262 BERTUGLIA, S.; COPPINI, G.; COLANTUONI, A. Effects of metformin on arteriolar vasomotion in normal and diabetic syrian hamsters. Diabetes Metab., v. 14, p. 554$559,1988$.

263 BERTUGLIA, S.; COLANTUONI, A.; DONATO, L. Effects of metformin on microcirculation during hemorrhagic shock. In: STRANO, A.; NOVO, S. (Ed.). Advances in Vascular Pathology. Amsterdam: Excerpta Medica, 1989. v. 2, p. 1189-1194.

264 BANDICK, N. R.; SPARKS, H., V. Contractile response of vascular smooth muscle of renal hypertensive rats. Am. J. Physiol., v. 219, p. 340-344, 1970.

265 HOLLOWAY, E. T.; BOHR, D. F. Reactivity of vascular smooth-muscle in hypertensive rats. Circ. Res., v. 33, p. 678-685, 1973.

266 OSOL, G.; HALPERN, W. Spontaneous vasomotion in pressurized cerebral arteries from genetically hypertensive rats. Am. J. Physiol., v. 254, p. H28-H33, 1988.

267 LAMB, F. S.; WEBB, R. C. Regenerative electrical activity and arterial contraction in hypertensive rats. Hypertension., v. 13, p. 70-76, 1989.

268 MULVANY, M. J.; AALKJÆR, C.; CHRISTENSEN, J. Changes in noradrenaline sensitivity and morphology of arterial resistance vessels during development of high bloodpressure in spontaneously hypertensive rats. Hypertension., v. 2, p. 664-671, 1980.

269 MYERS, J. H.; LAMB, F. S.; WEBB, R. C. Norepinephrine-induced phasic activity in tail arteries from genetically hypertensive rats. Am. J. Physiol., v. 248, p. H419-H423, 1985. 
270 BOONEN, H. C. M.; DEMEY, J. G. R. Increased calcium sensitivity in isolated resistance arteries from spontaneously hypertensive rats - Effects of dihydropyridines. Eur. J. Pharmacol., v. 179, p. 403-412, 1990.

271 SEKIGUCHI, F. et al. Effects of cyclopiazonic acid and thapsigargin on electromechanical activities and intracellular $\mathrm{Ca} 2+$ in smooth muscle of carotid artery of hypertensive rats. Br. J. Pharmacol., v. 118, p. 857-864, 1996.

272 BRUNER, C. A. et al. Genetic association of hypertension and vascular changes in stroke-prone spontaneously hypertensive rats. Hypertension., v. 8, p. 904-910, 1986.

273 MULVANY, M. J. Resistance vessel structure and function in the etiology of hypertension studied in F2-generation hypertensive normotensive rats. J. Hypertens., v. 6, p. 655-663, 1988.

274 SADA, T. et al. Cytosolic free calcium of aorta in hypertensive rats: Chronic inhibition of angiotensin converting enzyme. Hypertension., v. 16, p. 245-251, 1990.

275 WATTS, S. W.; TRAUB, O.; WEBB, R. C. Effects of ramipril on contractile oscillations in arteries from genetically hypertensive rats. Clin. Exp. Hypertens., v. 16, p. 881-898, 1994.

276 STRUIJKER BOUDIER, H. A. Arteriolar and capillary remodelling in hypertension. Drugs., v. 59, p. 37-40, 1999.

277 MEININGER, G. A.; LUBRANO, V. M.; GRANGER, H. J. Hemodynamic and microvascular responses in the hindquarters during the development of renal hypertension in rats: Evidence for the involvement of an autoregulatory component. Circ. Res., v. 55, p. 609$622,1984$.

278 HOLLENBERG, N. K., et al. Renal vasomotion in essential hypertension: Influence of vasodilators. Hypertension., v. 14, 9-13, 1989.

279 HOLLENBERG, N. K.; SANDOR, T. Vasomotion of renal blood-flow in essentialhypertension: Oscillations in xenon transit. Hypertension., v. 6, p. 579-585, 1984.

280 AALKJÆR, C.; et al. Abnormal vascular function and morphology in preeclampsia: A study of isolated resistance vessels. Clin. Sci. (Lond.)., v. 69, p. 477-482, 1985.

281 PASCOAL, I. F. et al. Preeclampsia selectively impairs endothelium-dependent relaxation and leads to oscillatory activity in small omental arteries. J. Clin. Invest., v. 101, p. 464-470, 1998.

282 KLARENBACH, S. W. et al. Differential actions of PAR2 and PAR1 in stimulating human endothelial cell exocytosis and permeability: the role of Rho-GTPases. Circ. Res. v. 92, n. 3, p. 272-278, 2003.

283 MARISKA, G. et al. Dynamics and Plasticity of Weibel-Palade Bodies in Endothelial Cells. Arterioscler. Thromb. Vasc. Biol., v. 26, p. 1002-1007, 2006. 
284 LI, J. et al. Enhanced G-protein coupled receptors-mediated contraction and reduced endothelium-dependent relaxation in hypertension. Eur. J. Pharmacol., v. 557, p. 186-194, 2007.

285 RAVEN, P. W. et al. Aldosterone secretion by the rat adrenal cortex is stimulated by the activation of protease-activated receptor 1. J.Endocrinol., v. 169, p. 581-585, 2001.

286 WOLIN, M. S.; GUPTE, S. A.; OECKLER, RA. Superoxide in the vascular system. J. Vasc. Res., v. 39, p. 191-207, 2002.

287 HIBBS Jr., J. B. et al. Nitric oxide: a cytotoxic activated macrophage effector molecule. Biochem. Biophys. Res. Commun., v. 157, p. 87 - 94, 1988.

288 SUZUKI, Y. J.; FORD, G. D. Superoxide stimulates IP3-induced Ca2+ release from vascular smooth muscle sarcoplasmic reticulum. Am. J. Physiol., v. 262, p. H114-H116, 1992.

289 JIN, N., PACKER, C. S., RHOADES, R. A. Reactive oxygen-mediated contraction in pulmonary arterial smooth muscle: cellular mechanisms. Can. J. Physiol. Pharmacol., v. 69, p. 383-388, 1991.

290 TOSTES, R. C. A.; MUSCARÁ, M. N. Endothelin Receptor Antagonists: Another Potential Alternative for Cardiovascular Diseases. Curr. Drug Targets - Cardiovasc. \& Haematol. Disorders., v. 5, n. 4, p. 287-301, 2005.

291 LEPAILLEUR-ENOUF, D. et al. Thrombin induces endothelin expression in arterial smooth muscle cells. Am. J. Physiol. Heart Circ. Physiol., v. 278, n. 5, p. H1606-H1612, 2000 .

292 YAMAZAKI, J.; FUJITA, N.; NAGANO, T. N ${ }^{\mathrm{G}}$-monomethyl-L-arginine-induced pressor response at developmental and established stages in spontaneously hypertensive rats. J. Pharmacol. Exp. Ther., v. 259, p. 52-57, 1991.

293 KELM, M. et al. Role of the nitric oxide in the regulation of coronary vascular tone in hearts from hypertensive rats: maintenance of the nitric oxide-forming capacity and increased basal production of nitric oxide. Hypertension., v. 25, p. 186-193, 1995.

294 NAVA, E.; NOLL, G.; LÜSCHER, T. F. Increased activity of constitutive nitric oxide synthase in cardiac endothelium in spontaneous hypertensive. Circulation., v. 91, p. 23102313, 1995.

295 JUNQUERO, D. C. et al. Enhanced production of nitric oxide in aorta from spontaneously hypertensive rats by interleukin-1 $\beta$. Am. J. Hypertens., v. 6, p. 602-610, 1993.

296 TSCHUDI, M. R. et al. Direct in situ measurement of nitric oxide in mesenteric resistance arteries: increased decomposition by superoxide in hypertension. Hypertension, $\mathrm{v}$. 27, p. 32-35, 1996. 
297 RUBANYI, G. M.; VANHOUTTE, P. M. Superoxide anions and hiperoxia in activate endothelium-derived relaxing factor. Am. J. Physiol., v. 250, p. H822-H827, 1986.

298 PARIK, T. et al. Oxidative stress and hyperinsulinemia in essential hypertension: differents facets of increased risk. J. Hipertens., v. 14, p. 407-410, 1996. 